\title{
JURISDICTION OVER A PARENT CORPORATION IN ITS SUBSIDIARY'S STATE OF INCORPORATION
}

\author{
WILLIAM A. VOXMAN $†$
}

\section{INTRODUCTION}

Jurisdiction over a parent corporation based on the ownership of a subsidiary ${ }^{1}$ has long been an unsettled issue. Plaintiffs frequently sue the parent corporation as well as the subsidiary for claims arising out of the actions of the subsidiary. Bringing suit against the parent can be especially important when the assets of the subsidiary are insufficient for complete recovery. Many times, such suits are brought in the forum in which the actions arose or where the subsidiary has its principal place of business. However, because corporations are always subject to jurisdiction in their states of incorporation, ${ }^{2}$ the claims against the parent and subsidiary will sometimes be brought in the subsidiary's state of incorporation.

Subsidiaries are often created for the purpose of limiting the liability of the parent corporation. The principle of limited corporate liability is deeply rooted in corporate law and is justified in terms of economic efficiency. ${ }^{3}$ Nonresident parent corporations ${ }^{4}$ often have minimal contacts with the states of incorporation

† B.A. 1989, Amherst College; J.D. Candidate 1993, University of Pennsylvania. I would like to extend special thanks to Professor A. Leo Levin for his many helpful insights and suggestions. This Comment is dedicated to my family and to my fiancée, Elizabeth Geib, for their moral support throughout the year.

1 For the purposes of this Comment, a subsidiary is defined as a corporation that is at least $50 \%$ owned by another corporation (the parent).

2 See 9 William M. Fletcher, Fletcher Cyclopedia of the LAW of PRIVATE CORPORATIONS $\$ 4309$ (perm. ed. rev. vol. 1985) [hereinafter FLETCHER]. In federal diversity actions, corporations are deemed to be citizens of both their states of incorporation and their places of principal business for purposes of jurisdiction. See 1 James W. MOORE et al., MoOre's Federal Practice I 0.77[1] (2d ed. 1992) (pointing out that corporations have dual citizenship under the 28 U.S.C. $\S 1332$ (c) (1958) amendment).

${ }^{3}$ See infra notes 85-92 and accompanying text.

${ }^{4}$ For the purposes of this Comment, a nonresident corporation is simply a corporation which is not incorporated in the state in question. The term "nonresident corporation" includes both domestic corporations (which are incorporated in another state) and foreign corporations (which are incorporated under the laws of another country). This distinction will typically be of little legal significance. In some cases, however, obtaining jurisdiction over a foreign corporation may be more difficult. See infra notes $45,51-54$ and accompanying text. 
of their subsidiaries. ${ }^{5}$ Yet a nonresident parent corporation that is forced to litigate claims against it or its subsidiary in its subsidiary's state of incorporation faces the additional costs and burdens associated with having to litigate in a forum with which the parent may have virtually no contacts. ${ }^{6}$ The imposition of such burdens on the nonresident parent corporation undermines the very purpose of creating the subsidiary-namely, limiting the parent's liability.

Delaware, for legal and financial reasons, is the state of incorporation of many American corporations. ${ }^{7}$ As a result of Delaware's attractiveness as a corporate domicile, nonresident parent corporations that choose to create subsidiaries often do so in Delaware. Clearly, whether these nonresident parent corporations will be subject to Delaware's jurisdictional reach and forced to incur the costs of litigating there is an issue of major consequence to them. Because so many Delaware corporations are subsidiaries of nonresident parent corporations, Delaware courts have had ample opportunity to address the specific issue of whether it is constitutional to assert jurisdiction over a nonresident parent in the subsidiary's state of incorporation.

This Comment examines the constitutional validity of subjecting a nonresident parent corporation to jurisdiction in its subsidiary's state of incorporation. Part I sets forth the United States Supreme Court's guidelines for exercising jurisdiction over nonresident parties. This discussion includes an analysis of how lower courts have applied those guidelines when parent and subsidiary corporations are involved. Part II begins by summarizing the principles applicable to determining whether the exercise of jurisdiction over a nonresident parent corporation in its subsidiary's state of incorporation is constitutional. The analysis then turns to some recent Delaware decisions which, in upholding the assertion of jurisdiction over nonresident parent corporations, interpret the

${ }^{5}$ It is often the case that the subsidiary will have no business connection to its state of incorporation and the parent corporation will have no connection to that state whatsoever, other than having purchased or incorporated the subsidiary at some point in time.

${ }^{6}$ See infra note 92 and accompanying text.

${ }^{7}$ See Jonathan R. Macey \& Geoffrey P. Miller, Toward an Interest-Group Theory of Delaware Corporate Law, 65 TEX. L. REV. 469, 483 (1987) (pointing out that over 40\% of New York Stock Exchange corporations are incorporated in Delaware and that $82 \%$ of corporations that reincorporate choose to do so in Delaware). Delaware's appeal as a state of incorporation stems from its "attractive mix of existing corporate law rules" and its "believable assurances that it will continue to supply such a desirable mix of rules in the future." Id. 
reach of the Delaware courts expansively. This Comment contends that the Delaware courts' expansive exercise of jurisdiction is unconstitutional.

\section{SUPREME COURT DOGTRINE FOR ESTABLISHING JURISDICTION OVER NONRESIDENT PARENT CORPORATIONS}

The question of whether state or federal courts have the constitutional authority to exercise jurisdiction over a nonresident parent corporation based on its ownership or incorporation of a subsidiary in the forum state has never been directly addressed by the United States Supreme Court. Two lines of cases have, however, shed some light on the issue. In Cannon Manufacturing Co. $v$. Cudahy Packing Co., ${ }^{8}$ the Court dealt directly with the general issue of jurisdiction in the context of a parent-subsidiary relationship. After Cannon, a series of cases beginning with Intermational Shoe Co. v. Washington ${ }^{9}$ have defined constitutional due process limitations on exerting jurisdiction over nonresident parties.

\section{A. The Cannon Doctrine}

In Cannon, a North Carolina corporation, Cannon Manufacturing Co. ("Cannon"), sought to bring an action in North Carolina against Cudahy Packing Company ("Cudahy"), a Maine corporation. Cannon attempted to serve process on Cudahy by delivering the summons and complaint to the Cudahy Packing Company of Alabama ("Cudahy Alabama"), an Alabama corporation which was a wholly owned subsidiary of Cudahy. ${ }^{10}$ Cudahy Alabama kept an office in North Carolina through which it conducted business in that state. ${ }^{11}$ Cudahy objected to service on the grounds that it was not doing business in North Carolina at the time. ${ }^{12}$ Cannon argued that Cudahy and Cudahy Alabama should be regarded as the

8267 U.S. 333 (1925).

9326 U.S. 310 (1945).

${ }^{10}$ See Cannon, 267 U.S. at 334.

11 See id. at $\mathbf{3 8 5}$.

12 The applicable jurisdiction test at the time of the Court's decision in Cannon was whether or not the defendant was present and doing business in the forum state. See id. at 334-35; Bank of Am. v. Whitney Cent. Nat'l Bank, 261 U.S. 171, 172 (1923); see also 4 Charles A. Wright \& ARThur R. Miller, Federal Practice and PROCEDURE § 1066 (2d ed. 1987) (discussing the "corporate presence" and "doing business" theories of jurisdiction). 
same entity for jurisdictional purposes. ${ }^{13}$

The Court rejected Cannon's argument and ruled that corporate separation was not to be ignored in the jurisdictional context. Relying on federal common law precedents, the Court noted that the use of a subsidiary to conduct business in the forum state was not sufficient to subject the parent corporation to that state's jurisdiction. ${ }^{14}$ According to the Court, the corporate separation between Cudahy and Cudahy Alabama was "in all respects observed," in that all transactions between the two corporations were recorded as if they were "wholly independent corporations." Thus, Justice Brandeis wrote, "[t]he corporate separation, though perhaps merely formal, was real. It was not pure fiction." ${ }^{16}$ In this context, the Court held that Cudahy was not subject to jurisdiction in North Carolina. ${ }^{17}$

Although the Court stated that no question of constitutionality

${ }^{13}$ See Cannon, 267 U.S. at 385.

I4 See id. at 336 (citing People's Tobacco Co. v. American Tobacco Co., 246 U.S. 79 (1918); Peterson v. Chicago, Rock Island \& Pac. Ry., 205 U.S. 364 (1907); and Conley v. Mathieson Alkali Works, 190 U.S. 406 (1903)). Justice Brandeis left open the possibility that Cannon might have been decided differently if Cudahy's liability for an act or omission of Cudahy Alabama had been at issue: "There is here no attempt to hold the defendant liable for an act or omission of its subsidiary .... Hence, cases concerning substantive rights ... have no application." Id. at 337 (citations omitted). Subsequent interpretations of Cannon, however, have ruled that the separation between a parent and subsidiary should be recognized for jurisdictional purposes even if the parent's substantive liability for an act or omission of the subsidiary is at issue. See infra notes $60-68$ and accompanying text.

${ }^{15}$ Cannon, 267 U.S. at $\mathbf{3 3 5 .}$

${ }^{16} I d$. at 397 . Courts today might have reached a different conclusion regarding the corporate separation between Cudahy and Cudahy Alabama, given that the Court in Cannon acknowledged that Cudahy "dominated" Cudahy Alabama "completely." Id. at 335; see infra notes 75-84 and accompanying text.

17 See Cannon, 267 U.S. at 338. The Court in Cannon discussed the concepts of "service of process" and "jurisdiction" interchangeably. In Cannon, service on Cudahy was improper because the summons was delivered to Cudahy Alabama, rather than Cudahy. Cannon's holding, however, goes beyond dismissing the action on the grounds of improper service: even if Cudahy had somehow been properly served, Cudahy would not have been subject to jurisdiction in North Carolina because it was not "present" or "doing business" in North Carolina. Thus, a nonresident party is not necessarily subject to a forum's jurisdiction even if service of process is effected in an apparently proper manner. See also Gallagher v. Mazda Motor of Am., Inc., 781 F. Supp. 1079, 1083 n.7 (E.D. Pa. 1992) (noting that even if the defendant could be properly served under the Hague Convention, plaintiffs would still have to show that defendant was subject to the forum's jurisdiction). This Comment discusses the circumstances under which courts can constitutionally exercise jurisdiction over a nonresident parent corporation regardless of the manner in which service of process is effected. 
was presented in Cannon, ${ }^{18}$ the doctrine that emerged from the Court's decision (the "Cannon doctrine") has, in the eyes of some lower courts, assumed constitutional dimensions. The doctrine is simple: a parent that retains "formal" and "real" separation from its subsidiary will not be subject to jurisdiction in a forum just because the subsidiary is subject to jurisdiction in that forum. ${ }^{19}$ Although many courts continue to adhere to the Cannon doctrine, other courts and commentators argue that it is no longer valid, partly because it is an example of federal common law which, in light of more recent Supreme Court decisions, must be subordinated to state common law. ${ }^{20}$

\section{B. The Minimum Contacts Test of International Shoe and its Progeny}

Many commentators also argue that Cannon has been superseded by the Supreme Court's so-called "minimum contacts" analysis first set forth in International Shoe Co. $v$. Washington. ${ }^{21}$ Instead of dealing with jurisdictional issues based on parent-subsidiary

${ }^{18}$ See Cannon, 267 U.S. at 336.

${ }^{19}$ Some commentators argue that Cannon is too formalistic in the sense that the mere existence of a parent-subsidiary relationship will almost always result in the recognition of the corporate separation between the parent and subsidiary for jurisdictional purposes. See PHILlIP I. BLUMBERG, THE LAW OF CORPORATE GroupS $\$ 3.03$ (1983) (commenting that the formalistic Cannon approach constitutes a "manipulation of abstractions"). The Cannon opinion does not clearly outline what standard should be used to determine whether a parent retains formal and real separation from its subsidiary, and the assumption that Cannon is to be applied formalistically is debatable. In fact, lower courts that have adhered to the Cannon doctrine often scrutinize the nature of parent-subsidiary relationships closely before determining whether that separation should be recognized for jurisdictional purposes. See infra notes 75-84 and accompanying text.

${ }^{20}$ Cannon was decided before Erie R.R. v. Tompkins, 304 U.S. 64 (1938). Prior to Erie, federal courts had developed a body of "federal common law" which often conflicted with state common law. See Murray E. Knudsen, Comment, Jurisdiction over a Corporation Based on the Contacts of a Related Corporation: Time for a Rule of Attribution, 92 DICK. L. REV. 917,924 n.48 (1988). Erie requires federal courts in diversity actions to apply the same substantive law that the forum-state's courts would apply. See Erie, $\mathbf{3 0 4}$ U.S. at 78. Thus, in light of Erie, the Cannon doctrine's validity is questionable since it can be considered an example of federal common law that is now subordinate to state common law. See BLUMBERG, supra note 19, § 3.03; Knudsen, supra, at 924.

21326 U.S. 910 (1945); see, e.g., BLUMBERG, supra note 19, \$ 3.03 (arguing that the Cannon doctrine has no constitutional relevance, especially after International Shoe); Knudsen, supra note 20, at 924 (arguing that the current validity of Cannon is questionable partly because it was decided prior to International Shoe, when federal courts could only exercise jurisdiction over "persons present in the forum"). 
relationships, the minimum contacts analysis focuses on whether it is fair and reasonable to force a nonresident party to litigate in a particular forum. International Shoe involved a shoe company ("International Shoe") which employed approximately thirteen salesmen in the State of Washington to distribute its products there. ${ }^{22}$ The Washington Supreme Court held that the salesmen's "systematic solicitation of orders" in the state was sufficient to support a finding that International Shoe did business in Washington and was therefore amenable to suit there. ${ }^{23}$ In upholding the constitutionality of the Washington Supreme Court's decision, the United States Supreme Court held that due process required that a nonresident party must have "certain minimum contacts with [a forum] such that the maintenance of [a] suit [there] does not offend 'traditional notions of fair play and substantial justice."'24 Under this standard, the Supreme Court determined that International Shoe's "systematic and continuous" activities in Washington constituted sufficient contacts with the state such that it would be "reasonable and just" to subject International Shoe to the jurisdiction of the Washington courts. ${ }^{25}$

The "minimum contacts" test of International Shoe was further explored in the corporate context in Shaffer $v$. Heitner. ${ }^{26}$ In Shaffer, the plaintiff brought a derivative suit against officers and directors of Greyhound, a Delaware corporation. The Delaware Court of Chancery exercised quasi in rem jurisdiction ${ }^{27}$ over the nonresident officers and directors by sequestering all of their stock in Greyhound. ${ }^{28}$ In affirming the chancery court's ruling, the Delaware

22 See International Shoe, 326 U.S. at $\mathbf{3 1 3 .}$

23 Id. at 314.

${ }^{24}$ Id. at 316 (citation omitted).

${ }^{25} I d$. at 320 .

26433 U.S. 186 (1977).

${ }^{27}$ Quasi in rem jurisdiction refers to an assertion of jurisdiction over a nonresident defendant where the contacts between the defendant and the forum state are not necessarily related to the subject of the litigation. The theory of quasi in rem jurisdiction is based on the notion that a state possesses exclusive jurisdiction over property within that state's boundaries. See 4 WRIGHT \& MILLER, supra note 12, $\$ 1070$. Under this theory, state courts can decide the fate of nonresident individuals' property even when those individuals could not otherwise be forced to litigate in that state. See id. Thus, when a nonresident defendant's property is attached or seized, the defendant is effectively forced to litigate claims in the forum state even if those claims are unrelated to the property, since failure to litigate the claims will result in a default judgment on the property. See id.

${ }^{28}$ See id. at 192. The stock of Delaware corporations is considered to be property located in Delaware. See DEL. CODE ANN. tit. 8, $\$ 169$ (1991). 
Supreme Court maintained that the International Shoe minimum contacts test was not applicable since the exercise of jurisdiction was "founded on the presence of capital stock here, not on prior contact by defendants with this forum." 29

The United States Supreme Court reversed and held that the minimum contacts test of International Shoe must be satisfied for a state to justify the exercise of quasi in rem jurisdiction. ${ }^{30}$ States can no longer attach a defendant's property for the purpose of forcing the defendant to litigate in their courts when the property is "completely unrelated to the ... cause of action." ${ }^{31}$ In Shaffer, there was simply no relationship between the nonresident directors' property (their Greyhound stock) and the litigation involving their duties as directors of the corporation. ${ }^{32}$

A significant result of Shaffer is that "the presence of ... [a defendant's] property alone" no longer suffices for a state to exercise jurisdiction. ${ }^{33}$ The Court's decision does not, however, prevent states from exercising jurisdiction over nonresident parties when the property itself is central to the dispute ${ }^{34}$ or when a controversy is related to "rights and duties growing out of" the ownership of property within the state. ${ }^{35}$

While Shaffer dealt specifically with the constitutionality of quasi in rem jurisdiction, the Court enumerated some of the more general factors courts must consider in determining whether jurisdiction over a nonresident is appropriate in World-Wide Volkswagen Corp. $v$. Woodson. ${ }^{36}$ One factor is whether a "defendant's conduct and connection with the forum State are such that he should reasonably

${ }^{29}$ Greyhound Corp. v. Heitner, 361 A.2d 225, 229 (1976), rev'd sub nom. Shaffer v. Heitner, 493 U.S. 186 (1977).

${ }^{30}$ See Shaffer, 433 U.S. at 207. The Court did point out that Delaware could exercise jurisdiction over nonresident directors or officers by other means. Delaware, unlike other states, had not yet enacted a statute establishing acceptance of a position as director or officer of a Delaware corporation as consent to jurisdiction in Delaware. See id. at 216. Had such a statute been enacted, jurisdiction over the directors would have presumably been deemed constitutional. Delaware has since enacted such a statute. See DEL. CODE ANN. tit. 10, $\$ 3114$ (Supp. 1990). For a discussion of the implications of a similar consent statute in the context of parent-subsidiary relationships, see infra notes $152 \& 184$.

${ }^{31}$ Shaffer, 433 U.S. at 209.

32 See id. at 213.

33 Id. at 209.

34 See id. at 207-08.

${ }^{35} \mathrm{Id}$. at 208. Here, the Court had in mind cases in which, for example, a plaintiff was injured on property that the defendant owned within the state. See id.

36444 U.S. 286 (1980). 
anticipate being haled into court there. ${ }^{n 37}$ For example, a defendant that has "purposefully avail[ed] itself of the privilege of conducting activities within the forum State" should reasonably anticipate being haled into court there for causes of action related to those activities. ${ }^{38}$ Other relevant factors are the forum state's interest in adjudicating the dispute, the plaintiff's interest in obtaining relief, and the judicial system's interest in obtaining the efficient resolution of controversies. ${ }^{39}$

In a subsequent decision, Helicopteros Nacionales de Colombia $v$. $\mathrm{Hall}^{40}$ the Court discussed constitutional jurisdictional requirements in terms of specific and general jurisdiction. "Specific" jurisdiction is present when "a controversy is related to or 'arises out of' a defendant's contacts with the forum. ${ }^{\text {"41 }}$ In order for a court's exercise of specific jurisdiction to comport with due process, a "relationship among the defendant, the forum, and the litigation" is essential. ${ }^{42}$

Even when specific jurisdiction is absent, a state may sometimes exercise "general" jurisdiction over a party. A party may be subject to the general jurisdiction of a forum state even when the litigation is completely unrelated to any activities that took place there. ${ }^{43}$ General jurisdiction is present only when a certain level of "continuous and systematic" contact exists between the nonresident and the

${ }^{37}$ Id. at 297.

${ }^{38}$ Id. (quoting Hanson v. Denclia, 357 U.S. 235, 253 (1958)). The Court reasoned that once a defendant has purposefully availed itself of such a privilege, "it has clear notice that it is subject to suit there, and can act to alleviate the risk of burdensome litigation by procuring insurance, passing the expected costs on to customers, or, if the risks are too great, severing its connection with the State." Id.

${ }^{39}$ See id. at 292 . In a subsequent case, Burger King Corp. v. Rudzewicz, 471 U.S. 462 (1985), the Court pointed out that a defendant need not "physically enter" the forum state in order to be subject to suit there. Id. at 476. Instead, if a party "purposefully direct[s]" its efforts towards residents of another state, it will be subject to that state's jurisdiction provided that sufficient minimum contacts exist. Id. (quoting Keeton v. Hustler Magazine, 465 U.S. 770, 774 (1984)). In Burger King, the Court ruled that the defendant, a franchisee of the Burger King restaurant chain, was subject to jurisdiction in Florida in light of having "entered into a carefully structured 20-year relationship that envisioned continuing and wide-reaching contacts with Burger King in Florida." Id. at 480.

40466 U.S. 408,414 nn.8-9 (1984).

41 Id. at 414 (citations omitted).

42 Id. (quoting Shaffer v. Heitner, 433 U.S. 186, 204 (1977)). An example of such a relationship would be the commission of an allegedly tortious act by a nonresident defendant in the forum state. "Specific" jurisdiction would only exist over claims that arose from or were related to that tortious act.

43 For example, corporations are subject to general jurisdiction in their states of incorporation. See supra note 2 and accompanying text. 
forum state. ${ }^{44}$

Finally, the Court has recently recognized that there may be instances in which jurisdiction would not comport with due process even when minimum contacts have been established between the defendant and the forum state. In Asahi Metal Industry Co. v. Superior Court, ${ }^{45}$ plaintiff Zurcher had brought a products liability suit against a Taiwanese tire manufacturer ("Cheng Shin"). ${ }^{46}$ Cheng Shin, in turn, filed a cross-complaint against a Japanese tire valve manufacturer ("Asahi"). ${ }^{47}$ Zurcher's claims against Cheng Shin were eventually settled out of court, but Cheng Shin's claim against Asahi remained. ${ }^{48}$

Writing for the Court, Justice O'Connor emphasized that the only claim remaining before the California courts was Cheng Shin's indemnification claim against Asahi. ${ }^{49}$ Furthermore, the transaction involved in that claim-Asahi's sale of tire valves to Cheng Shin-had taken place in Taiwan and had very little to do with the State of California (except that the tires which had caused Zurcher's injury had eventually ended up there). ${ }^{50}$ California's interests in adjudicating the dispute were deemed slight compared to the burden on Asahi to litigate this particular claim in a foreign country. ${ }^{51}$ O'Connor also noted that " $[t]$ he unique burdens placed upon one who must defend oneself in a foreign legal system should have significant weight in assessing the reasonableness of stretching

14 Helicopteros, 466 U.S. at 415. Helicopteros involved a wrongful death action stemming from a helicopter crash in South America in which four Americans were killed. See id. at 410. The plaintiffs instituted the action in Texas against a number of defendants, including Helicol, a Colombian corporation. See id. at 412 . Helicol was the owner of the helicopters at the time and had entered into a contract in Peru to provide the helicopters for transportation purposes in South America. See id. at 410. Helicol's only contacts with Texas consisted of sending an executive officer there for contract negotiations, accepting checks drawn on a Houston bank, purchasing helicopters from a Texas company, and sending personnel to helicopter training facilities in Fort Worth. See id. at 416. All of the parties agreed that the claims against Helicol did not "arise out of" Helicol's activities in Texas, and therefore specific jurisdiction was absent. Id. at 415 . The Court held that Helicol's contacts with Texas were not of a "continuous and systematic" nature and therefore would not justify Texas's exercise of general jurisdiction over Helicol. Id. at 416.

15480 U.S. 102 (1987).

16 See id. at 106 .

17 See id.

${ }^{48}$ See id.

19 See id. at 114.

${ }^{50}$ See id.

31 See id. 
the long arm of personal jurisdiction over national borders." 52 Under these circumstances, O'Connor concluded that California's exercise of jurisdiction over Asahi would be "unreasonable and unfair."

While the Court was unanimous in holding that jurisdiction over Asahi was unconstitutional, the Court was divided on the question of whether Asahi had, in fact, established minimum contacts with California. Justice O'Connor was joined by three Justices in concluding that minimum contacts had not been established. ${ }^{54}$ Four Justices maintained that Asahi had established minimum contacts by placing allegedly defective tire valves into the stream of commerce with the expectation and/or knowledge that some of the valves would end up in California. ${ }^{55}$ These Justices concluded that California's exercise of jurisdiction would be unreasonable and unfair (and therefore unconstitutional) despite the existence of minimum contacts between Asahi and California. ${ }^{56}$ Justice Stevens found it unnecessary to determine whether minimum contacts were present, arguing that this was an instance in which jurisdiction over Asahi would be unconstitutional regardless of whether such contacts existed. ${ }^{57}$ Thus, five Justices agreed that in cases such as this one, a forum's exercise of jurisdiction over a litigant might not comport with due process despite the existence of minimum contacts between that litigant and the forum.

\section{The Continuing Validity of the Cannon Doctrine in Light} of Erie and the International Shoe Minimum Contacts Test

As mentioned previously, many commentators have argued that the Cannon doctrine is no longer valid both because it must now be subordinated to state common law in light of Erie, and because it has been superseded by the International Shoe minimum contacts test. $^{58}$ In addition to being called into question by subsequent Supreme Court decisions, Cannon has been further undermined by many lower court decisions which have held that it is no longer valid in their jurisdictions. ${ }^{59}$

\footnotetext{
32 Id.

${ }^{53}$ Id. at 116.

54 See id. at 112-13.

${ }^{55}$ See id. at 116 (Brennan, J., concurring in part and concurring in the judgment).

${ }^{56}$ See id.

${ }^{57}$ See id. at 121 (Stevens, J., concurring in part and concurring in the judgment).

${ }^{58}$ See supra notes $20-21$ and accompanying text.

${ }^{39}$ For example, in Brunswick Corp. v. Suzuki Motor Co., 575 F. Supp. 1412 (E.D.
} 
Despite its many criticisms and apparent disavowals, a strong argument can be made that the Cannon doctrine still does and should constitute good law. One commentator has suggested that the Court in Cannon may have been asserting a sort of "natural law" of corporations under which formally separate corporations should be treated as separate for jurisdictional purposes. ${ }^{60}$ One sign that the Cannon doctrine is still valid is that the Supreme Court has never repudiated it despite having had occasion to do so. ${ }^{61}$ In

Wis. 1983), the court ruled that Cannon was no longer relevant to the constitutional inquiry into whether jurisdiction comported with due process. See id. at 1419. In Brunswick, plaintiff Brunswick Corporation brought a patent infringement suit in Wisconsin against, among others, Hitachi Ltd. ("Hitachi"), a Japanese corporation, and Mitsubishi Electric Corporation ("MELCO"), also a Japanese corporation. See id. at 1415. Neither Hitachi nor MELCO had ever directly conducted business in Wisconsin, although both corporations sold products in Wisconsin through wholly owned subsidiaries. See id. at 1415-16. In rejecting the continuing validity of Cannon, the court stated that "the constitutional analysis under International Shoe permits consideration of a non-resident's contacts with the forum state through its wholly owned subsidiaries without regard to whether the affiliated corporations have maintained a formal separation of corporate identities." Id. at 1419. Under this standard, the court ruled that it could constitutionally exercise jurisdiction over MELCO and Hitachi because the Japanese corporations had "avail[ed] themselves of the benefits and protections of [Wisconsin]" by selling products there through their wholly owned subsidiaries. Id. at 1422-23.

Similarly, in Gallagher v. Mazda Motor of Am., Inc., 781 F. Supp. 1079 (E.D. Pa. 1992), the court rejected the Cannon doctrine in favor of another approach. Under Gallagher, "if a parent uses a subsidiary to do what it otherwise would have done itself, it has purposely availed itself of the privilege of doing business in the forum [and j]urisdiction ... is therefore proper." Id. at 1085. Thus, an analysis of the nature of the parent subsidiary relationship, which is required under Cannon, is completely unnecessary under Gallagher.

Some state courts have also apparently rejected the Cannon doctrine. See, e.g., Empire Steel Corp. v. Superior Court, 366 P.2d 502, 506 (Cal. 1961) (pointing out that "Cannon was not decided on the basis of the due process limitation on assertion of jurisdiction by a court").

${ }_{60}$ See Lea Brilmayer \& Kathleen Paisley, Personal Jurisdiction and Substantive Legal Relations: Corporations, Conspiracies, and Agency, 74 CAL. L. REV. 1, 3 (1986).

61 Some commentators have argued that the Court took a step toward repudiating the Cannon doctrine in United States v. Scophony Corp. of America, 383 U.S. 795 (1948). Scophony involved a special venue statute under the Clayton Act through which service of process was effected by serving the American subsidiary of a British parent corporation. See id. at $796 \& \mathrm{n}$.1. The Court ruled that the service was valid under $\$ 12$ of the Clayton Act and distinguished the case from Cannon in that this case was not a "manufacturing or selling" case. Id. at 816. Although the court did appear to retreat from Cannon, it did so only in the context of antitrust actions stating that it was "unwilling to construe $\$ 12$ in a manner to bring back the evils it abolished." Id. at 817 . Thus, it is not altogether clear what weight should be given to Scophony in cases not involving antitrust actions. See Akzona Inc. v. E.I. Du Pont de Nemours \& Co., 607 F. Supp. 227, 239 (D. Del. 1984) (arguing that Scophony is distinguishable from Cannon in that it applies a more lenient jurisdictional standard 
fact, the Court may have implicitly recognized the doctrine's continuing validity in Keeton $v$. Hustler Magazine. ${ }^{62}$ In a footnote of Keeton, Chief Justice Rehnquist noted that "jurisdiction over a parent corporation [does not] automatically establish jurisdiction over a wholly owned subsidiary . . . . Each defendant's contacts with the forum State must be assessed individually. "63 The clear implication of Rehnquist's assertion is that the nature of the parentsubsidiary relationship may well be a factor in determining whether jurisdiction comports with due process, but the existence of the relationship will not, in and of itself, be dispositive of the issue.

The strongest indication that Cannon retains vitality is that it is cited as both valid and current legal doctrine in a significant number of both state and federal court opinions. In Escude Cruz v. Ortho Pharmaceutical Corp., ${ }^{64}$ for example, the plaintiff alleged that Ortho Pharmaceutical Corporation ("OPC"), a New Jersey corporation, and its wholly owned subsidiary, Ortho Pharmaceuticals, Inc. ("OPI"), a Puerto Rican corporation, were responsible for workrelated injuries the plaintiff suffered while working at OPI in Puerto Rico. ${ }^{65}$ The Puerto Rican Workmen's Compensation Act immunizes employers against claims arising from work-related injuries, however, so the plaintiff's only hope of obtaining recovery was to file suit against OPC. ${ }^{66}$ In affirming the lower court's dismissal of the suit against OPC for lack of jurisdiction, the court adhered to the Cannon doctrine, pointing out that "[t]he mere fact that a subsidiary company does business within a state does not confer jurisdiction over its nonresident parent, even if the parent is sole owner of the subsidiary. ${ }^{n 7}$ The court further noted that the presumption of corporate separateness must be overcome by evidence that the parent in fact controls the activities of the subsidiary, and no such evidence had been presented. ${ }^{68}$

only to $\$ 12$ of the Clayton Act).

62465 U.S. 770 (1984).

${ }^{63}$ Id. at 781 n.13 (citations omitted).

64619 F.2d 902 (1st Cir. 1980).

65 See id. at 903-04.

${ }^{66}$ See id. at 904.

${ }^{67}$ Id. at 905 (citing Cannon Mfg. Co. v. Cudahy Packing Co., 267 U.S. 333, 336 (1925)).

${ }^{68}$ See id. Similarly, in Bielicki v. Empire Stevedoring Co., 741 F. Supp. 758 (D. Minn. 1990), plaintiffs sued defendant Empire Stevedoring Company ("Empire Canada"), a Canadian corporation, in Minnesota claiming that Minnesota courts could exert jurisdiction over Empire Canada based on the incorporation of its wholly owned subsidiary, Empire Stevedoring, Inc. ("Empire Duluth”) in Minnesota. See id. at $\mathbf{7 6 0 .}$ 
Most courts that still adhere to the Cannon doctrine do not employ a purely "formalistic" approach in determining whether corporate separation between the parent and subsidiary exists. Instead, courts tend to scrutinize the nature of the parent-subsidiary relationship to determine whether the parent and subsidiary should, in fact, be treated as separate entities. ${ }^{69}$

In addition to the lower court decisions which still explicitly recognize Cannon, there are some decisions which appear to reject the Cannon doctrine but are actually consistent with it. In Coca-Cola Co. v. Procter $\mathfrak{F}^{2}$ Gamble Co., for example, Coca-Cola sued Procter \& Gamble in Georgia for tortious interference with a contract. ${ }^{70}$ Although Procter \& Gamble did not conduct business in Georgia, many of its subsidiaries did. The court held that Georgia could exercise personal jurisdiction over Procter \& Gamble based on its "pervasive and tight control" over subsidiaries that conducted business in Georgia." ${ }^{71}$ In so holding, the court seemed to reject the Cannon doctrine when it ruled that the "harsh strictures" of the Cannon doctrine were no longer applicable because the holding of Cannon had been "substantially refined" by International Shoe and its progeny. ${ }^{72}$ Despite this apparent disavowal of Cannon, the court's decision in Coca-Cola is not inconsistent with the Cannon doctrine. The Cannon doctrine simply states that jurisdiction over a subsidiary

The court began its analysis by adopting the Cannon doctrine, stating that "[a] corporation is not doing business in a state merely by the presence of its wholly owned subsidiary." Id. at 761. In this case, however, the court held that the exercise of jurisdiction over Empire Canada would comport with due process because plaintiffs had set forth sufficient evidence that Empire Canada exercised enough control over Empire Duluth for the court to "disregard the corporate identity of Empire Duluth." Id. at 762. In other words, the corporate separation between Empire Canada and Empire Duluth was analogous to the "pure fiction" Justice Brandeis alluded to in Cannon. Cannon, 267 U.S. at 387. The court ultimately held that the exercise of jurisdiction was invalid, however, because the Minnesota long-arm statute authorized specificjurisdiction but not general jurisdiction, and plaintiffs had not shown any specific connection between the acts complained of and Empire Canada's business activities in Minnesota. See Bielicki, 741 F. Supp. at 764; see also Graco, Inc. v. Kremlin, Inc., 558 F. Supp. 188, 190 (N.D. Ill. 1982) (citing Cannon for the proposition that the mere existence of a parent-subsidiary relationship is not sufficient to make the parent amenable to suit in a jurisdiction where the subsidiary is located); Idaho Potato Comm'n v. Washington Potato Comm'n, 410 F. Supp. 171, 179 (D. Idaho 1976) (same); Botwinick v. Credit Exch. Co., 213 A.2d 349, 353 (Pa. 1965) (adopting Cannon).

${ }^{69}$ See infra notes 75-84 and accompanying text.

70595 F. Supp. 304, 306 (N.D. Ga. 1983).

71 Id. at 308 .

72 Id. at $307-08$. 
will not automatically establish jurisdiction over the parent corporation when "formal" and "real" separation between the parent and subsidiary is maintained. In Coca Cola, the court's decision that jurisdiction over Procter \& Gamble comported with due process was reached only after a lengthy analysis of the relationship between Procter \& Gamble and its subsidiaries. This analysis revealed that the subsidiaries were "equivalent to departments or divisions of [Procter \& Gamble]. ${ }^{\text {73 }}$ The ruling that jurisdiction was proper was therefore consistent with the Cannon doctrine since the court found that formal separation between the parent and subsidiaries had not been maintained. ${ }^{74}$

Thus, many state and federal courts adhere (either explicitly or implicitly) to the principles first embodied in Cannon when making jurisdictional determinations in cases involving parent and subsidiary corporations. ${ }^{75}$ The tests which these courts use to evaluate parent-subsidiary relationships for jurisdictional purposes often vary in their terminology, but the tests are actually very similar. In New York, for example, courts exercise jurisdiction over foreign parent corporations if their subsidiaries are the "agents" or "mere departments" of their corporate parents (assuming the subsidiaries are subject to jurisdiction in New York). ${ }^{76}$ Courts in other states exercise jurisdiction over nonresident parent corporations by virtue of the actions of their subsidiaries when the subsidiaries are the "alter-egos" or "instrumentalities" of the parent corporations. ${ }^{77}$

The Delaware District Court's decision in Akzona Inc. v. E.I. Du Pont de Nemours $\mathcal{F}^{2} \mathrm{Co}^{78}$ evidences the similarity between agents, instrumentalities and alter-egos. In defining these terms, the Akzona

${ }^{73} I d$. at 308.

74 Cannon's standard for determining whether corporate separation between a parent and subsidiary exists may have been too formalistic for the court in Coca-Cola (although an actual standard for making such a determination was not really established in Cannon). Still, as mentioned at infra notes 75-84 and accompanying text, courts may scrutinize the existence of corporate separation between a parent and subsidiary more closely than Brandeis did in Cannon without being inconsistent with the Cannon doctrine. A court's decision will be consistent with the Cannon doctrine so long as the ultimate jurisdictional determination hinges on the existence (or lack) of corporate separation between the parent and subsidiary, regardless of whether a formalistic standard is used in making that determination.

${ }^{75}$ See, e.g., BLUMBERG, supra note $19, \$ 3.05$ (pointing out that most federal courts still adhere to Cannon); see also supra notes 60-74 and accompanying text.

${ }^{76}$ See BLUMBERG, supra note 19, §§ 4.01-.06 (discussing New York jurisdictional law in the context of parent-subsidiary relationships).

77 See id. \$§ 5.03-.10 (discussing the jurisdictional standards of various states).

${ }^{78} 607$ F. Supp. 227 (D. Del. 1984). 
court stated that "[i]n order to find that a subsidiary is the alter ego or instrumentality of the parent, the plaintiff must prove: 'control by the parent to such a degree that the subsidiary has become its mere instrumentality."'79 Similarly, a finding that a subsidiary is a parent's agent involves "a determination that the separate corporate identities of the subsidiary and parent are a fiction and that the subsidiary is, in fact, being operated as a department of the parent. The parent must have actual, participatory and total control of the subsidiary. ${ }^{n 0}$

As Akzona makes clear, the main factor in deciding whether a subsidiary is a parent's agent, instrumentality, or alter-ego is the extent to which the parent exercises control over the subsidiary. In this sense, the jurisdictional analysis of a parent-subsidiary relationship parallels the corporate-veil-piercing analysis used to determine a parent's substantive liability for the actions of its subsidiary. ${ }^{81}$ Other factors relevant to the determination of whether to pierce the corporate veil for both jurisdictional and substantive liability purposes include the extent to which the parent finances the subsidiary, whether the parent owns all of the subsidiary's stock, whether the parent caused the incorporation of the subsidiary, whether the parent and subsidiary have common officers and directors, and whether the subsidiary is undercapitalized. ${ }^{82}$

If, after going through this analysis, a court determines that a parent and subsidiary are legitimately separate corporate entities, contacts with the forum aside from the ownership of a subsidiary

79 Id. at 237 (quoting Steven v. Roscoe Turner Aeronautical Corp., 324 F.2d 157, 160 (7th Cir. 1963)).

${ }^{80}$ Id. (citations omitted). For a more complete discussion of the methods courts use in determining whether a subsidiary's actions should be attributed to those of the parent corporation, see Brilmayer \& Paisley, supra note 60, at 15-39.

${ }^{81}$ See 1 FLETCHER, supra note 2, $\$ 43.70$ (perm. ed. rev. vol. 1990) (discussing instances in which courts will ignore the separation between the parent and subsidiary for jurisdictional purposes); Knudsen, supra note 20, at 919. Although courts employ similar analyses in the context of jurisdiction as they do in the context of substantive liability, the standards for acquiring jurisdiction are not as strict as the applicable tests in liability cases in that fraud or wrongaioing are not required elements for a finding of jurisdiction over the absent corporation. See 1 FLETCHER, supra note $2, \S 43.70$ (perm. ed. rev. vol. 1990); see alio 18A. FLETCHER, supra note 2, \$ 8773 (perm. ed. rev. vol. 1988) (discussing factors relevant to the determination of whether a parent and subsidiary should be considered separate entities for the purpose of serving process on foreign parent corporations).

${ }^{82}$ See Bielicki v. Empire Stevedoring Co., 741 F. Supp. 759, 761-62 (D. Minn. 1990); see also 1 FLeTCHER, supra note 2, $\$ \$ 41,41.10$ (perm. ed. rev. vol. 1990) (discussing similar factors used to determine whether the corporate veil should be pierced for purposes of substantive liability). 
will generally be necessary in order to subject the parent to the forum's jurisdiction. ${ }^{83}$ In this sense, the law appears to integrate aspects of the Cannon doctrine into the minimum contacts analysis: although a parent's ownership of a subsidiary incorporated or conducting business in the forum state constitutes a contact with the forum state, a more lengthy veil-piercing analysis is necessary before it can be determined whether this contact alone suffices under the International Shoe minimum contacts test. ${ }^{84}$

\section{The Justification for Continued Adherence to Cannon}

The continued adherence to Cannon is fully justifiable because the Cannon doctrine is based on sound legal and economic principles. One of the deeply rooted principles of the law of corporations is that stockholders of a corporation are not to be held personally responsible for the liabilities of a corporation. ${ }^{85}$ This

83 For example, in Ryder Truck Rental v. Acton Foodservices Corp., 554 F. Supp. 277 (C.D. Cal. 1983), plaintiff brought a breach of contract action against defendant Acton Foodservices and its corporate grandparent, Beltran; a Delaware corporation, in California. See id. at 278. Beltran had no contacts with California other than its indirect ownership of Acton. The court granted Beltran's motion to dismiss for lack of jurisdiction because no showing had been made that Beltran and Acton were not legitimately separate corporate entities. See id. at 279 . The court noted that " [s]ole ownership of the subsidiary by the parent is not enough; in addition, there must be 'clear evidence that the parent in fact controls the activities of the subsidiary." Id. (quoting Escude Cruz v. Ortho Pharmaceutical Corp., 619 F.2d 902, 905 (1st Cir. 1980)); see also Williams v. Canadian Fishing Co., 509 P.2d 64, 67 (Wash. App. 1973) (holding that ownership of a subsidiary was not itself sufficient to establish jurisdiction); 18A FLETCHER, supra note 2, $\$ 8773$ (perm. ed. rev. vol. 1988) ("[M]ere stock ownership by the parent of the subsidiary is not sufficient in and of itself to charge the parent company with responsibility for the acts of the subsidiary, and such ownership does not constitute the requisite 'minimum contact' necessary to establish jurisdiction over the parent company.").

${ }^{84}$ In this sense, the law is consistent with then-Justice Rehnquist's reasoning in Keeton v. Hustler Magazine, 465 U.S. 770 (1984). See supra notes 62-63 and accompanying text. Some courts argue that the inquiry into whether a subsidiary is an agent, alter-ego, or instrumentality is different from the jurisdictional test of Cannon because Cannon's approach was concerned only with "corporate form." See Gallagher v. Mazda Motor of Am., Inc., 781 F. Supp. 1079, 1083-84 (E.D. Pa. 1992). As mentioned previously, it is debatable whether Cannon requires a purely formalistic approach. Even if such an approach were required at one time, most courts which presently adhere to Cannon do not employ an overly formalistic approach. See supra notes 19, 75-84 and accompanying text. Thus, the distinction between the test involved in determining whether the subsidiary is an agent, alter-ego, or instrumentality of a parent and the approach espoused by modern applications of Cannon is, at most, minimal.

${ }^{85}$ See 13A FLETCHER, supra note 2, \$§ 6213-6214 (perm. ed. rev. vol. 1984) (outlining the general rule that stockholders are not liable for the debts or acts of 
general principle is also applicable to parent and subsidiary corporations: a parent corporation's mere ownership of all or part of the stock of a subsidiary corporation does not make the parent liable for the debts or actions of the subsidiary. ${ }^{86}$

Just as there are many economic reasons for limiting the liability of shareholders of corporations, ${ }^{87}$ there are sound reasons for limiting a parent corporation's liability for the debts and actions of its subsidiary. If the liability of related corporations (such as parents and subsidiaries) were not limited, unrelated corporations would be able to obtain competitive advantages over related corporations. For example, taxi cab corporations that own many taxi cabs often incorporate each cab separately (as a subsidiary) in order to limit any liability from accidents to the particular cab involved in the accident. If the individual cabs of a larger company could not be incorporated separately in such a manner, "true" single cab firms would have a significant competitive advantage in terms of lower operation costs: the liability of the "true" single company would be limited to its few assets (i.e., the single cab), while the larger multi-cab company could be liable to the extent of the full value of all of its assets, including the other cabs not involved in the accident. This competitive advantage for unrelated corporations would result in inefficiencies because the advantages of economies of scale derived from forming larger corporations would be foregone. ${ }^{88}$

The most notable exception to the general rule of non-liability of a parent corporation is the situation in which the corporate separation between the parent and subsidiary is not legitimately maintained, or is, as Justice Brandeis wrote in Cannon, "pure fiction." 89 When corporate separation is not legitimately maintained, the "corporate veil" will be pierced and the parent corporation will be held substantively liable for the debts or acts of its subsidiaries. ${ }^{90}$ The piercing of the corporate veil protects credi-

corporations in which they own shares).

${ }^{86}$ See id. \$ 6222.

${ }^{87}$ See, e.g., Frank H. Easterbrook \& Daniel R. Fischel, Limited Liability and the Corporation, 52 U. CHI. L. REV. 89, 93-98 (1985) (discussing the economic rationale for limiting the liability of shareholders).

88 See id. at 111.

${ }^{89}$ See Cannon Mfg. Co. v. Cudahy Packing Co., 267 U.S. 333, 337 (1925); 13A FLETCHER, supra note 2, § 6222 (perm. ed. rev. vol. 1984).

${ }^{90}$ See supra notes 75-84 and accompanying text for a discussion of relevant factors in determining when the corporate veil should be pierced for jurisdictional purposes. 
tors of the subsidiary and ensures that managers of the parent corporation do not engage in a "socially excessive amount of risky activities." $" 91$

Cannon simply applies this principle of limited liability to cases in which the issue is whether jurisdiction should be exercised over the parent corporation based on the actions of its subsidiary. If a parent and subsidiary are legitimately separate corporate entities, then the parent will not be liable for the actions of its subsidiary. If a parent must nevertheless litigate claims stemming from the actions of its subsidiary in a forum where it would not otherwise be subject to jurisdiction, the parent corporation will be exposed to the burdens associated with having to litigate in a forum with which it has negligible contacts, even if the final outcome is the exoneration of the parent corporation. These burdens include increased litigation $\operatorname{costs}^{92}$ and the possibility that the forum's laws may be unfavorable to the corporation. In addition, the parent corporation's officers and directors may have to divert much of their attention away from more productive matters to the litigation. The imposition of such burdens on the parent corporation runs counter to the very purpose of limiting the liability of the parent corporation in the first place and therefore arguably offends traditional notions of fair play and substantial justice. Thus, the integration of the Cannon doctrine (and the general principles of limited corporate liability) into the International Shoe test is both legally and economically justifiable.

\section{JURISDICTION OVER A PARENT CORPORATION IN ITS SUBSIDIARY'S STATE OF INCORPORATION}

The preceding analysis provides a general framework for determining when a court can appropriately exercise jurisdiction over a parent corporation based on the actions of its subsidiary. Litigation in this context arises very often in the subsidiary's

91 Easterbrook \& Fischel, supra note 87, at 111.

92 A corporation that is forced to litigate in a forum with which it has virtually no contacts is likely to incur litigation costs above those that would be incurred in a forum with which the corporation has many contacts. These additional costs include, but are not limited to, attorney's fees for local counsel, paying travel expenses for executives and/or witnesses and the general costs associated with becoming familiar with the laws of a particular forum. These added costs are likely to have the most significant impact on foreign corporations (especially those that are not otherwise amenable to suit in the United States) and on small to medium-sized domestic corporations. 
principal place of business or in a forum where a subsidiary does substantial business. Part II, however, will deal only with the specific issue of when a parent will be subject to jurisdiction in its subsidiary's state of incorporation. An important factor to keep in mind throughout this discussion is that corporations often have virtually no relationship with their states of incorporation (unlike with their principal states of business). Delaware, for example, is the state of incorporation of a significant number of the United States' largest corporations, but most of those corporations do very little, if any, business in Delaware, and very few of them actually have their principal places of business in Delaware. Given that a subsidiary may have virtually no relationship to its state of incorporation, a nonresident parent corporation is likely to have even less of a connection to its subsidiary's state of incorporation. Very often, the parent's only relationship to that state will be that it once filed documents necessary to incorporate its subsidiary there.

This part begins by summarizing the constitutional issues specifically applicable to a determination of whether a parent can be subjected to jurisdiction in its subsidiary's state of incorporation. This summary is followed by an analysis of recent Delaware decisions in which nonresident parent corporations of Delaware subsidiaries have been subjected to the jurisdiction of the Delaware courts.

\section{A. The Constitutional Appropriateness of Exercising Jurisdiction Over a Nonresident Parent Corporation in its Subsidiary's State of Incorporation}

Even though the Supreme Court has never directly addressed the issue of when jurisdiction over a parent corporation in the subsidiary's state of incorporation is appropriate, the decisions in Cannon and International Shoe and its progeny lay out the basic framework necessary to make such a determination. If only the Cannon doctrine were applied, a parent corporation would not be subject to jurisdiction in the state of incorporation of its subsidiary (absent any other contacts with the state) so long as formal separation between the parent and subsidiary existed. On the other hand, if the subsidiary were the agent, alter-ego, or instrumentality of the parent, the separation would be more analogous to the "pure fiction" mentioned by Justice Brandeis in Cannon, and jurisdiction over the parent corporation would be valid under the Cannon doctrine. 
The constitutional issue is not so simple in light of International Shoe and its progeny, especially under the hypothetical assumption that International Shoe has rendered the Cannon doctrine obsolete. To the extent that Shaffer holds that ownership of property in the forum state is not itself sufficient to justify jurisdiction over a nonresident property owner, the mere ownership of the stock of a subsidiary should not subject a nonresident parent to the forum's jurisdiction. ${ }^{93}$

Shaffer implies more, however: if the cause of action is related to the property, then jurisdiction may be valid. In this sense, the argument can be made that a suit alleging wrongdoing on the part of a subsidiary is related to a nonresident parent corporation's property (i.e., its ownership of the subsidiary's stock). There is reason to think that the Shaffer Court would have rejected this argument. The types of claims to which the Shaffer Court was probably referring differ from those which would most likely arise in the parent-subsidiary context. For example, the Court would likely have upheld jurisdiction if the controversy involved claims to the property itself. ${ }^{94}$ Yet this type of claim would not arise in the parent-subsidiary context unless the ownership of the subsidiary's stock itself were at issue.

The Court also stated that jurisdiction might be appropriate for claims where the cause of action is related to "rights and duties" growing out of the ownership of the property such as suits for injury suffered on the land of a nonresident owner. ${ }^{95}$ However, in Shaffer, the Court's decision invalidating jurisdiction over the nonresident directors did not hinge on the fact that the nonresident directors only owned a small percentage of Greyhound stock. Instead, the court ruled that there was simply no relationship between the directors' duties as directors (at issue in the suit) and their ownership of some of Greyhound's stock. ${ }^{96}$ Nothing in Shaffer implies that the Court would have reached a different result had the nonresident directors owned large percentages of Greyhound stock. Thus, after Shaffer, the question pertinent to a

99 See, e.g., Shaffer v. Heitner, 433 U.S. 186, 216 (1977) (“‘ $[I] \varepsilon$ strains reason ... to suggest that anyone buying securities in a corporation formed in Delaware "impliedly consents" to subject himself to Delaware's . . . jurisdiction on any cause of action." ) (quoting Ernest L. Folk III \& Peter F. Moyer, Sequestration in Delaware: A Constitutional Analysis, 73 ColuM. L. REv. 749, 785 (1973)).

94 See Shaffer, 438 U.S. at 207.

95 Id. at 208.

96 See id. at 213. 
jurisdictional determination in the parent-subsidiary context is whether ownership of a subsidiary's stock is unrelated to a cause of action stemming from the acts of the subsidiary. A strong argument can be made that because a parent and subsidiary are legally separate entities and the law of corporations limits the liability of stockholders, mere ownership of a subsidiary's stock bears no relation to causes of action arising out of the acts of a subsidiary when the corporate separation between the parent and subsidiary is legitimately maintained. ${ }^{97}$ Thus, just as directors' duties to their corporations are unrelated to their ownership of stock, a parent's ownership of a subsidiary's stock is arguably unrelated to the actions of the subsidiary. Consequently, Shaffer ought not to allow jurisdiction over a parent based solely on its ownership of the stock of a subsidiary.

The standard enunciated in World-Wide Volkswagen also dictates against exercising jurisdiction over a parent corporation based only on its ownership of the stock of a subsidiary. After World-Wide Volkswagen, the issues central to determining a parent corporation's amenability to suit in its subsidiary's state of incorporation are: (1) whether a parent "purposefully avails" itself of the privilege of conducting activities in the forum state when it incorporates a subsidiary there, and (2) whether a parent corporation can "reasonably anticipate" being haled into court in the state of incorporation of its subsidiary. ${ }^{98}$ The proposition that the incorporation of a subsidiary constitutes purposeful availment of the laws of the subsidiary's state of incorporation has little merit. There is little difference in principle between incorporating (or purchasing) a subsidiary in a state and purchasing or building a house there. In both cases there may be a benefit to utilizing the laws of the forum state, ${ }^{99}$ but in neither case should a party be amenable to suit in that state for causes of action unrelated to the ownership of the property. Furthermore, in most cases, a parent that maintains legitimate separation from its subsidiary will probably not "reasonably anticipate" being haled into court in the state of incorporation of its subsidiary. After all, many jurisdictions have followed the Cannon doctrine for 65 years by requiring more than a showing of

97 This argument would be especially compelling if the Supreme Court were explicitly to reaffirm the principles embodied in Cannon.

${ }_{98}$ World-Wide Volkswagen Corp. v. Woodson, 444 U.S. 286, 297 (1980).

99 In building a house, there may be favorable building codes or tax advantages in particular states, for example. 
ownership over a subsidiary in order for jurisdiction to be asserted over a nonresident parent.

The nature of the relationship between the parent and subsidiary becomes important in the context of the Court's decision in Helicopteros. If the separation between the parent and subsidiary is fictitious, and they are, for practical purposes, the same entity, then the parent is arguably subject to general jurisdiction wherever the subsidiary is subject to general jurisdiction, including the subsidiary's state of incorporation. ${ }^{100}$ If corporate separation is legitimately maintained, the parent would be subject to specific jurisdiction in the subsidiary's state of incorporation only if the litigation "arises" out of the parent's actions in that state, such as incorporating, purchasing, or even exercising control over some of the actions of the subsidiary. ${ }^{101}$

Finally, Asahi points out that there may be some instances in which jurisdiction would not comport with due process even if minimum contacts between a party and the forum exist. ${ }^{102}$ Subjecting a parent to suit in the state of incorporation of its subsidiary solely on the basis of its having incorporated that subsidiary may well be one such instance in which jurisdiction would be unconstitutional even the if the ownership of the stock of the local subsidiary were considered a minimum contact. This inference is supported by the corporate law principle favoring limited shareholder liability, especially when shareholders do not exercise complete control over the activities of the corporations in which they own stock. ${ }^{103}$

The above analysis reveals that there are no constitutional problems to subjecting a parent that incorporates a subsidiary as an alter-ego, agent, or instrumentality to jurisdiction in the subsidiary's state of incorporation. Such a result would be consistent with both Cannon and the International Shoe minimum contacts cases. As alluded to previously in Part I, a strong argument can be made that Cannon has been integrated into the International Shoe minimum

100 Under such circumstances, the parent corporation would be considered to have a "continuous and systematic" contact with the subsidiary's state of incorporation. See Helicopteros Nacionales de Colombia v. Hall, 466 U.S. 408, 416 (1984).

${ }^{101}$ See id. at 414 n.8.

102 See supra notes $45 \& 5457$ and accompanying text.

103 Another implication of Asahi is that the burdens of litigating in a foreign country should be given significant weight in a court's decision of whether to exercise jurisdiction over a corporation organized under the laws of a foreign country. See Asahi Metal Indus. Co. v. Superior Court, 480 U.S. 102, 114 (1987). 
contacts analysis, and rightly so. ${ }^{104}$ If this is the case, the force of the Cannon doctrine should bear heavily on situations in which a parent establishes a subsidiary that is a legitimately separate corporate entity. In such instances, the parent's incorporation and ownership of the subsidiary's stock may be relevant factors in determining if minimum contacts with the subsidiary's state of incorporation exist, but should not be treated as contacts sufficient to satisfy the International Shoe test. Even if one were to reject the proposition that Cannon has been integrated into International Shoe, however, the International Shoe minimum contacts cases raise serious doubts as to the constitutional validity of subjecting a nonresident parent corporation to the jurisdiction of its subsidiary's state of incorporation based solely on its ownership of that subsidiary's stock.

\section{B. Delaware's Expansive Exercise of Jurisdiction}

Whether a parent corporation should be subject to the jurisdiction of its subsidiary's state of incorporation is an issue not likely to arise frequently before courts in much of the United States. In many cases, both the parent and subsidiary are incorporated in the same state, while in other cases suits are brought in the subsidiary's principal place of business, a state often different from the subsidiary's state of incorporation. Delaware, however, has a unique tendency to attract a disproportionate number of corporations to incorporate within its borders. Not surprisingly, the Delaware courts have had ample opportunity to examine this issue at length. The Delaware Supreme Court has construed the jurisdictional reach of its courts very expansively and has, in most cases, held that jurisdiction over the nonresident parent was proper. The Delaware decisions are of great significance not only because so many nonresident corporations choose to incorporate subsidiaries there, but also because many other states look to Delaware corporate law for guidance in developing their own corporate law.

The following four hypothetical situations illustrate possible justifications for subjecting a nonresident parent of a Delaware subsidiary to jurisdiction in Delaware: 1) the local subsidiary is the alter-ego, agent, or instrumentality of the parent; 2) the cause of action arises out of the very act of incorporating (or purchasing) the subsidiary; 3) the parent, by incorporating (or purchasing) the

104 See supra notes 60-92 and accompanying text. 
subsidiary, sets in motion a chain of events from which the cause of action arises; or 4) the parent, by opting not to reincorporate the subsidiary in another state, chooses to operate the subsidiary as a Delaware corporation, thereby availing itself of the benefits of Delaware law.

The first example merits little discussion. The corporate separation between the parent and the subsidiary is essentially fictitious when a subsidiary is a parent's alter-ego, agent, or instrumentality, and the parent and subsidiary should be treated as the same entity. Therefore, under both the Cannon doctrine and the International Shoe minimum contacts test (as well as a test integrating the two lines of cases), the parent can be regarded as having the same contacts to the subsidiary's state of incorporation as does the subsidiary. As a result, the exercise of jurisdiction over the parent in the subsidiary's state of incorporation comports with both due process and principles of limiting corporate liability. ${ }^{105}$ The situation is more complex, however, when corporate formalities between the parent and subsidiary are, in fact, observed and the actions of a subsidiary cannot be imputed to the parent. Assuming that such formalities are observed and the parent and subsidiary are legitimately separate entities, the latter three hypothetical situations present constitutional questions which are discussed below.

\section{Jurisdiction Over a Nonresident Parent When the Cause of Action Arises Out of the Act of Incorporating or Purchasing the Subsidiary}

In Sears, Roebuck Eै Co. v. Sears PLC ${ }^{106}$ ("Sears II" and "Sears $\left.I I I^{n}\right)$, the court faced an instance in which the cause of action allegedly arose from a foreign parent's act of incorporating a subsidiary in Delaware. Plaintiff Sears, Roebuck sued Sears PLC ("PLC") for infringing its trade name (and trademark) by causing its

105 The implication of this result is that the parent would be subject to jurisdiction in Delaware for causes of action completely unrelated to acts of the subsidiary. This is not unjustified, however, since the subsidiary's Delaware citizenship could be attributed to the parent by virtue of the lack of separation between the parent and subsidiary.

106744 F. Supp. 1297 (D. Del. 1990) [hereinafter Sears II]; 752 F. Supp. 1223 (D. Del. 1990) [hereinafter Sears III]. Although Sears II and Sears III were decided in different opinions, they both arose from the same litigation. See also Sears, Roebuck \& Co. v. Sears PLC, 744 F. Supp. 1289 (D. Del. 1990) [Sears I]. Sears I involved a motion to dismiss by a British subsidiary of a British parent corporation and is therefore inapplicable to the issues addressed in this Comment. See id. at 1291. 
subsidiaries to use the name "Sears." Originally, PLC had incorporated "Sears, Inc." in Delaware, intending that it be a holding company of other American subsidiaries (owned directly or indirectly by PLC). ${ }^{107}$ Sears, Roebuck immediately brought a claim against Sears, Inc. for alleged trade name infringement. Sears, Inc. agreed to change its name to Delaware Mercantile Holdings, Inc. ("DMH") as part of a settlement in this phase of the litigation. ${ }^{108}$ Although this portion of the dispute was never fully litigated, it seems obvious that, for this claim at least, the cause of action arose from PLC's very act of incorporating Sears, Inc. DMH's former use of the name Sears, Inc., after all, stemmed from PLC's act of incorporating DMH in Delaware. ${ }^{109}$ Thus, had the court been faced with a complaint against PLC in this specific portion of the litigation, it would have been completely justified in exercising jurisdiction over PLC because "by incorporating a subsidiary in Delaware . . . PLC performed an act in state sufficient to confer personal jurisdiction over it for causes of action related to that act of incorporation." 110

The court's decision was not limited to a ruling on trade name infringement claims against DMH. Those claims were apparently settled out of court. ${ }^{11}$ Sears, Roebuck's complaint against PLC alleged that PLC caused both its Delaware and non-Delaware subsidiaries to use the name "Sears" in violation of Sears, Roebuck's trade name. PLC's motion to dismiss for lack of jurisdiction over these claims was granted in part and denied in part. The claims against PLC for the trade name infringements of its Delaware subsidiaries were not dismissed, ${ }^{112}$ while the claims against PLC

107 See Sears II, 744 F. Supp. at 1299.

108 See id.

${ }^{109}$ At this juncture, it should be noted that a majority of states, including Delaware, authorize one or more persons, including corporations, to act as "incorporators" of business corporations. See 1A FLETCHER, stupra note 2, § 85 (perm. ed. rev. vol. 1983). The fact that a parent corporation can incorporate a subsidiary itself is important for jurisdictional purposes because if the subsidiary had been incorporated by individuals not acting as agents of Sears PLC then Sears PLC could not be said to have "incorporated" the subsidiary and therefore may not have performed the "act of incorporation" in Delaware.

110 Sears II, 744 F. Supp. at 1308.

111 See Sears II, 744 F. Supp. at 1299 (stating that Sears, Roebuck's complaint against DMH was dismissed without admission of liability and with prejudice when DMH agreed, as part of the settlement, that neither it nor any of its subsidiaries would use the name "Sears").

112 See id. at 1303 (upholding jurisdiction over PLC for claims involving DMH); see also Sears III, 752 F. Supp. at 1230 n.11 (upholding jurisdiction over PLC for 
for the actions of its non-Delaware subsidiaries were dismissed.113 Although the court in Sears II seemed to rely primarily on its theory that jurisdiction over PLC for the actions of its Delaware subsidiaries was justified because of PLC's jurisdictional act of incorporating $\mathrm{DMH},{ }^{114}$ a close reading of Sears $I I$ and the court's subsequent decision in Sears III reveals that the court ultimately relied more heavily on a different theory, namely a "limited agency theory." Sears, Roebuck established that PLC sufficiently "directed and controlled" its Delaware subsidiaries' use of the trade name Sears so as to be subject to jurisdiction in Delaware. ${ }^{116}$ Thus, it appears that jurisdiction over PLC was not, in the end, based primarily on PLC's having effected the incorporation of DMH (since whatever

claims involving a Delaware subsidiary other than DMH).

113 The court ruled that the exercise of specific jurisdiction over PLC for alleged trade name infringements of PLC's non-Delaware subsidiaries "would run afoul of due process" because none of those infringements arose out of PLC's contacts with Delaware. Sears III, 752 F. Supp. at 1228.

114 This reliance on DMH's single jurisdictional act is somewhat curious. Assuming that DMH was a separate corporate entity from PLC (a fact that was under dispute), it could hardly be said that DMH's acts of trade name infringement, other than its own previous use of the name Sears, were related to PLC's act of incorporating DMH. The court did not explain how the alleged trade name infringement by Delaware subsidiaries other than DMH was specifically related to PLC's act of incorporating $D M H$. In fact, it seems likely that the alleged infringement by these subsidiaries was completely unrelated to the actual act of incorporating DMH.

${ }^{115}$ In Sears $I I$, the court analyzed the nature of the relationship between PLC and DMH and found that a limited agency relationship existed: PLC "directed and controlled" DMH in the accomplishment of infringing plaintiff's trade name. Sears II, 744 F. Supp. at 1306 (quoting Altech Indus. Inc. v. Al Tech Specialty Steel, 542 F. Supp. 53, 55 (D. Del. 1982)). In a footnote, the court noted that "specific jurisdiction over PLC may also be predicated under this limited agency theory." Id. at $1306 \mathrm{n} .7$. The Sears court relied on Altech as precedent for finding this agency relationship. In Altech, plaintiff Altech Industries alleged trade name infringement against GATX and its Delaware subsidiary Al Tech Specialty Steel ("Al Tech"). Al Tech became GATX's subsidiary not because it was incorporated by GATX, but by virtue of GATX's acquisition of Al Tech's stock. The court noted that "[ $\mathrm{t}]$ he mere acquisition by GATX of all of the stock of defendant Al Tech violated no right of the plaintiff; standing alone it gave rise to no cause of action. The wrong occurred when ... GATX directed and controlled the defendant Al Tech in infringing plaintiff's trade name." Altech, 542 F. Supp. at 55 (emphasis added). Similarly, it would seem that PLC's incorporation of DMH, standing alone, did not give rise to the cause of action against PLC for trade name infringement allegations against its subsidiaries, other than DMH's onetime use of the name Sears, which was presumably settled out of court.

116 See Sears III, 752 F. Supp. at 1224, 1230 n.11. It is not clear whether the Sears court's "limited agency theory" constituted a finding that PLC's Delaware subsidiaries were agents, alter-egos, or instrumentalities of PLC. Had such a finding clearly been made, PLC would have arguably been subject to general jurisdiction in Delaware since the Delaware citizenship of its subsidiaries could have been attributed to PLC. 
wrongs arose out of DMH's one-time use of the trade name "Sears, Inc." were apparently dealt with in an out of court settlement between DMH and Sears, Roebuck), but was based on the premise that DMH and other subsidiaries were sufficiently controlled by PLC so as to attribute their trade name infringements to PLC through a limited agency relationship. ${ }^{117}$ Still, the court never disavowed its reliance in Scars II on PLC's act of incorporating DMH as one basis for exercising jurisdiction over PLC for claims against subsidiaries other than DMH.

Thus, the Sears cases are consistent with constitutional jurisdictional standards to the extent they stand for the limited proposition that when a jurisdictional act, such as incorporating a subsidiary, in and of itself wrongfully harms a plaintiff, the parent corporation will be subject to specific jurisdiction in the subsidiary's state of incorporation. ${ }^{118}$ This proposition is consistent with the specific jurisdiction test of Helicopteros. ${ }^{119}$ It is conceivable that the court's holding in the Sears cases could be construed more broadly to include claims that do not arise from the specific act of incorporating a subsidiary (such as the alleged trade name infringements of subsidiaries other than DMH). Such a broad construction of Sears would raise constitutional concerns since it is difficult to conceive how the tortious acts by subsidiaries other than DMH arose from or were even remotely related to the specific act of incorporating DMH. In such case, the Supreme Court's requirement in Helicopteros that the controversy be "related to" or "arise out of" the defendant's contacts with the forum would appear not to have been met. ${ }^{120}$

117 At least one judge has interpreted the court's holding in this manner. In Applied Biosystems v. Cruachem, Ltd., 772 F. Supp. 1458 (D. Del. 1991), Judge Roth relied on Sears $I I I$ in determining that courts could consider the "acts by [an] agent which were directed by the principal" to provide the basis for jurisdiction over the principal. Id. at 1467 (citing Sears III, 752 F. Supp. at 1225).

${ }^{118}$ Similarly, it follows that if the purchase of a subsidiary is wrongful, the parent will be subject to claims arising therefrom in the state of incorporation of the subsidiary.

${ }^{119}$ In addition, this result is not inconsistent with Cannon because Cannon did not involve facts where jurisdiction over the parent corporation could have been based on specific acts committed by the parent corporation in the forum. See Cannon Mfg. Co. v. Cudahy Packing Co., 267 U.S. 333 (1925).

120 This requirement would clearly be met if the Sears court's primary reliance were on the limited agency theory, however, in which case the controversies would arise out of PLC's contacts with its subsidiaries since the actions of the subsidiaries could be attributed to PLC. Thus, a "relationship among the defendant, the forum, and the litigation" would be properly established. See Helicopteros Nacionales de 
One way it could be argued that the Helicopteros tests for specific or general jurisdiction had been satisfied, given the facts in Sears (absent a finding of an agency, instrumentality, or alter-ego relationship), would be to assert that the act of incorporating a subsidiary "gave rise" to all subsequent wrongful acts committed by the subsidiary. The act of incorporating the subsidiary in the first place would, after all, be a "but for" cause of any subsequent acts committed by the subsidiary. Whether this causal link suffices to make the parent amenable to the forum's jurisdiction is discussed in the following subsection. ${ }^{121}$

Another argument is that the incorporation of a subsidiary constitutes purposeful availment of the laws of the state of incorporation and thereby makes the incorporator amenable to suit for any controversies arising out of the subsidiary's actions. This argument is discussed below as well in , subsections three to five. ${ }^{122}$

2. Jurisdiction Over the Nonresident Parent When the Incorporation of the Subsidiary Sets in Motion a Chain of Events Culminating in the Cause of Action

In 1975, Helmut Papendick contacted officials at Robert Bosch GmbH ("Bosch"), a West German corporation, concerning a company that Papendick felt would be a good acquisition candidate for Bosch. ${ }^{123}$ Papendick agreed to disclose the name of this company to Bosch in consideration of a "finders fee."124 Upon receiving a "finders fee agreement" from Bosch, Papendick disclosed the name of Borg-Warner Corporation ("Borg-Warner") as the acquisition candidate. ${ }^{125}$ A formal contract was subsequently signed between Bosch and Borg-Warner providing for the purchase and receipt of two million shares of Borg-Warner's stock by Bosch or an assignee. Just days prior to signing the contract with

Colombia v. Hall, 466 U.S. 408, 414 (1984) (quoting Shaffer v. Heitner, 433 U.S. 186, 204 (1977)). Similarly, no constitutional problems would be presented if the Sears court had unequivocally held that PLC's Delaware subsidiaries were the agents, alteregos, or instrumentalities of PLC, since jurisdiction could have been based on a general jurisdiction theory under such a holding. See supra notes $43-44$ and accompanying text.

121 See infra notes 123-46 and accompanying text.

122 See infra notes 147-92 and accompanying text.

123 See Papendick v. Bosch, 410 A.2d 148, 149 (Del. 1979), cert. denied, 446 U.S. 909 (1980).

124 See id.

125 See id. 
Borg Warner, Bosch incorporated a subsidiary in Delaware, later named Robert Bosch North America Incorporated ("RBNA"), to serve as a "vehicle for the acquisition of the [Borg-Warner] stock."126 Bosch designated RBNA as the recipient of the shares of Borg-Warner stock purchased pursuant to the agreement. Bosch subsequently refused to pay the finders fee to Papendick and plaintiff filed an action against both Bosch and RBNA in Delaware. ${ }^{127}$ Bosch moved to dismiss for lack of jurisdiction claiming, in part, that "'mere' ownership by [Bosch] of the stock of RBNA, which does not do business in Delaware and is not the 'alter ego' of [Bosch], is an insufficient contact upon which to assert jurisdiction. ${ }^{\text {128 }}$

The Delaware Superior Court dismissed the action against Bosch due to the similarities between this case and the United States Supreme Court's decision in Shaffer. ${ }^{129}$ As in Shaffer, jurisdiction over Bosch was allegedly obtained by serving RBNA's registered agent in Delaware and attaching the stock Bosch owned in RBNA. ${ }^{130}$ Furthermore, the contract between Bosch and plaintiff from which the cause of action arose was not entered into in Delaware and had nothing to do with the State of Delaware. ${ }^{131}$ As in Shaffer, the Superior Court ruled that Bosch's ownership of RBNA stock was insufficient to subject Bosch to jurisdiction in Delaware:

[Bosch's stock ownership in RBNA] has no relevance to the present litigation and the mere incorporation of a subsidiary corporation in Delaware does not create a sufficient contact with the State to expose [Bosch] to a situation which could amount to in personam liability....

To decide that incorporation is qualitatively sufficient is not different from holding that the presence of the stock alone is enough to meet constitutional standards for jurisdiction. ${ }^{132}$

The Delaware Supreme Court rejected this argument and ruled that jurisdiction over Bosch was appropriate. ${ }^{133}$ The court distin-

${ }^{126} \mathrm{Id}$.

127 See id.

${ }^{128} I d$. at 150 .

${ }^{129}$ See Papendick v. Bosch, 389 A.2d 1315 (Del. Super. 1978), rev'd, 410 A.2d 148

(Del. 1979), cert. denied, 446 U.S. 909 (1980).

130 See id. at 1316.

131 See id. at 1318.

132 Id. at 1318-19.

133 See Papendick v. Bosch, 410 A.2d 148 (Del. 1979), cert. denied, 446 U.S. 909 
guished the case from Shaffer stating that there were significant contacts between Bosch, the State of Delaware, and the litigation: ${ }^{134}$

[Bosch] came into the State of Delaware to create, under the Delaware Corporation Law, a subsidiary corporation for the purpose of implementing its contract with [Borg-Warner] and accomplishing its acquisition of [Borg-Warner] stock. [Bosch] utilized the benefits and advantages of Delaware's Corporation Law for the creation of RBNA to be the vehicle for channeling to [Borg-Warner] the purchase money for the [Borg-Warner] stock and for becoming the recipient of the [Borg-Warner] stock. ...

$\cdots$

... [Bosch] purposefully availed itself of the benefits and protections of the laws of the State of Delaware for financial gain in activities related to the cause of action. Therein lies the 'minimum contact' sufficient to sustain the jurisdiction of Delaware's courts over [Bosch]. ${ }^{135}$

Thus, the court concluded that this was a case in which the cause of action was related to Bosch's contacts with Delaware. ${ }^{136}$ The court did not find it necessary to address the issue of whether RBNA was the alter-ego, instrumentality, or agent of Bosch when it acquired Borg-Warner's stock. Based on the facts of the case, it seems relatively obvious that such a finding could have been made and, as a result, jurisdiction over Bosch would clearly have been

(1980).

${ }^{134}$ Here, the Delaware Supreme Court appears to be referring to the test for specific jurisdiction enunciated in Helicopteros by the United States Supreme Court: "When a controversy is related to or 'arises out of' a defendant's contacts with the forum, the Court has said that a 'relationship among the defendant, the forum, and the litigation' is the essential foundation of in personam jurisdiction." Helicopteros Nacionales de Colombia v. Hall, 466 U.S. 408, 414 (1984) (quoting Shaffer v. Heitner, 433 U.S. 186, 204 (1977)). The Helicopteros test, therefore, is two-part. In addition to a relationship between the forum, the litigation, and the defendant, the controversy must arise from or be related to defendant's contacts to the forum. See id. Thus, in order to satisfy the Helicopteros test, the Delaware Supreme Court should have defined how plaintiff's claims arose from Bosch's sole contact with Delaware, its incorporation of RBNA.

${ }^{135}$ Papendick, 410 A.2d at 152.

136 Papendick's holding was followed in Rabkin v. Philip A. Hunt Chem. Corp., 547 A.2d 963, 966 (Del. Ch. 1986), where the court held that jurisdiction over a nonresident parent corporation existed where the parent had incorporated a Delaware subsidiary in order to effectuate a merger around which the lawsuit was centered. 
warranted. ${ }^{137}$ The court also accorded little weight to the fact that the contract in dispute had not been entered into in Delaware and was between a resident of Maryland and a West German corporation. ${ }^{138}$

In reaching its decision that jurisdiction over Bosch was proper, the court relied primarily on the notion that Bosch, by incorporating RBNA and thereby taking advantage of the benefits of Delaware law, had set in motion a chain of events which culminated in RBNA's receipt of Borg-Warner's stock. ${ }^{139}$ The court's reliance on this reasoning is justifiable to the extent that Bosch's incorporation of RBNA was a necessary cause of the transaction from which plaintiff's claim arose: had Bosch not incorporated RBNA, the stock exchange between RBNA and Borg-Warner would not have taken place. However, the same argument could be made of a parent corporation that incorporated a subsidiary three years prior to the subsidiary's involvement in an alleged tort: had the subsidiary not been incorporated, it would not have committed the tort. Yet unlike the factual scenario in Papendick, the tort that was eventually committed by the subsidiary in the latter example would not, in all likelihood, have been within the parent's contemplation when the subsidiary was incorporated three years earlier. The court's opinion in Papendick lacks a requirement that the parent's jurisdictional act bear a sufficiently close relationship to the ensuing litigation to satisfy the United States Supreme Court's test for specific jurisdiction outlined in Helicopteros. ${ }^{140}$

Courts in Illinois have come close to making such a requirement in their interpretations of the Illinois long-arm statute. ${ }^{141}$ In

197 See supra notes 75-84 and accompanying text. The exercise of jurisdiction on these grounds would have been consistent with both Cannon and the International Shoe minimum contacts analysis. See supra notes 93-104 and accompanying text.

${ }^{138}$ It is important to note that in cases such as this one, the action could have been brought in the forum where the contract was entered into, Maryland, or in Bosch's country of incorporation, West Germany. Thus, forums other than Delaware were, in all probability, available to plaintiff.

${ }_{139}$ See supra text accompanying note 135.

140 Absent such a requirement, there may be cases involving different facts that apply the reasoning of Papendick to exercise jurisdiction over a nonresident parent corporation even though the relationship between the jurisdictional act and the litigation is not sufficiently close to satisfy due process.

Had the court found that an agency or alter-ego relationship between Bosch and RBNA existed, there would have been no question that plaintiff's harm was related to Bosch's contacts with Delaware since RBNA's actions could be attributed to Bosch under a general jurisdiction theory.

141 Delaware's long-arm statute is based on Illinois' statute. See Sears III, 752 F. 
order for jurisdiction to be present in Illinois, the jurisdictional act (which the incorporation of RBNA represented in Papendick) must be a "critical step[] in the chain of events" that culminates in the cause of action before the court. ${ }^{142}$ Although, the facts in Papendick appear to support a finding of jurisdiction over Bosch under the Illinois test, the Delaware Supreme Court did not adopt this critical step requirement. Instead, the court used broad language stating that minimum contacts between Delaware and Bosch existed because Bosch, by incorporating RBNA and using it as a vehicle for the contested transaction, had "purposefully availed itself of the benefits and protections of the laws of the State of Delaware for financial gain in activities related to the cause of action." 143 Thus, Papendick could be construed to permit the exercise of jurisdiction over a parent whose act of incorporating a subsidiary was not closely related to the cause of action. ${ }^{144}$

The "critical step" test adopted by the Illinois courts seems to increase the probability that the cause of action will be sufficiently related to or arise from the parent corporation's act of incorporating the subsidiary to satisfy the Helicopteros specific jurisdiction requirement. Nonetheless, the critical step test also has potential deficiencies. The test could conceivably encompass some instances

Supp. 1223, 1225 n.6 (D. Del. 1990) ("Delaware courts have traditionally relied on the judicial interpretations of Illinois' long arm statute . . . because Delaware's long arm statute was modeled on that of Illinois.").

${ }^{142}$ In re Oil Spill by Amoco Cadiz off Coast of France, 699 F.2d 909, 917 (7th Cir. 1983), cert. denied sub nom., Astilleros Espanoles, S.A. v. Standard Oil Co., 464 U.S. 864 (1983) (emphasis added). In Sears III, the court adopted the Illinois court's line of reasoning in ruling that jurisdiction was absent in Delaware for claims against PLC's non-Delaware subsidiaries. See Sears III, 752 F. Supp. at 1227-28.

${ }^{143}$ Papendick v. Bosch, 410 A.2d 148, 152 (Del. 1979), cert. denied, 446 U.S. 909 (1980).

${ }^{144}$ In Red Sail Easter Ltd. Partners v. Radio City Music Hall Prods., No. 12036, 1991 Del. Ch. LEXIS 113 (July 10, 1991), plaintiffs asserted breach of contract claims against a nonresident parent corporation and its Delaware subsidiaries. See id. at *1. The nonresident parent corporation's only act in Delaware was to cause the incorporation of its Delaware subsidiaries many years previously. See id. at *4. The court ruled that the claims against the parent corporation were "in no sense" related to the parent's having incorporated the subsidiaries in Delaware and that the cause of action therefore did not "arise" from any acts committed by the parent corporation in Delaware. Id. at *7. The court's decision in Red Sail was based on the absence of jurisdiction under the Delaware long-arm statute, and a constitutional analysis was therefore unnecessary. See id. at *6-*7. Still, the court's finding that defendant's claims did not "arise" from the act of incorporation would presumably have been the same under a constitutional analysis. Thus, the Delaware Chancery Court would apparently construe Papendick narrowly, thereby avoiding the potential constitutional problems that would arise if Papendick were construed broadly. 
in which the subsidiary's wrongful act really has little to do with the parent's sole jurisdictional act of incorporating the subsidiary. ${ }^{145}$ In such instances, the parent corporation would be subject to jurisdiction for causes of action not arising from or related to the jurisdictional acts of the parent in the state-a result violative of due process under Helicopteros.

Rather than tolerate the critical step test's potential constitutional deficiencies, courts should examine the facts of each case to determine whether the subsidiary was the alter-ego, instrumentality, or agent of the parent. In such cases, courts could confidently assert that the parent had sufficient control over the subsidiary's role in the cause of action to make the parent amenable to jurisdiction for claims arising out of the subsidiary's actions wherever the subsidiary could be tried for such claims. This result would be consistent with both the Cannon doctrine and the International Shoe minimum contacts test. ${ }^{146}$

As mentioned previously, the facts in Papendick clearly indicate that the court could have found that RBNA had acted as Bosch's agent, alter-ego, or instrumentality in the purchase of BorgWarner's shares, thereby rendering Bosch subject to Delaware's jurisdiction. Therefore, the Delaware Supreme Court undoubtedly reached the correct result in exercising jurisdiction over Bosch. Notwithstanding the result, the reasoning underlying the court's opinion in Papendick may potentially conflict with Cannon and the International Shoe minimum contacts test.

\section{Jurisdiction Over a Nonresident Parent by Virtue of its Ownership of a Delaware Subsidiary}

Stermberg $v . O^{\prime} \mathrm{Neil}^{147}$ is the most controversial and potentially far-reaching jurisdictional decision handed down by the Delaware Supreme Court in the context of parent-subsidiary relationships. Sternberg involved a double derivative action ${ }^{148}$ against GenCorp,

145 For example, a parent might incorporate a subsidiary, and on the next day, an employee of the subsidiary could negligently cause a fire in another state, perhaps in the subsidiary's state of principal business. The act of incorporating the subsidiary may well have been a critical step towards the occurrence of the next day's accident since the employee would not even have had a job with the subsidiary if it had not existed. It is hard to imagine, though, how the act of incorporating the subsidiary would actually be related to the fire.

${ }_{146}$ See supra notes 93-104 and accompanying text.

147550 A.2d 1105 (Del. 1988).

148 Double derivative suits enable shareholders of a parent corporation to sue on 
an Ohio corporation, and RKO General ("RKO"), a wholly owned Delaware subsidiary of GenCorp. The complaint alleged that officers and directors of GenCorp and RKO had breached their fiduciary duties to GenCorp shareholders by making numerous false and misleading statements to the FCC. ${ }^{149}$

The Delaware Chancery Court dismissed the claims against GenCorp for lack of jurisdiction and against RKO for failure to join an indispensable party, namely GenCorp. ${ }^{150}$ The court recognized that GenCorp, by registering to do business in Delaware, had appointed an agent to receive service of process in Delaware and, therefore, had arguably consented to general jurisdiction in Delaware. ${ }^{151}$ Nevertheless, the court ruled that the United States Supreme Court's minimum contacts test must be met even in cases where jurisdiction over a party is based on statutory consent. ${ }^{152}$ The court noted that GenCorp's only contacts with Delaware were its registration to do business in Delaware and its purchase of RKO more than 30 years previously. ${ }^{153}$ These acts had no connection

behalf of a subsidiary even if the shareholders do not own any of the subsidiary's stock. The action is based on the fact that the parent corporation, by virtue of its ownership of the subsidiary's stock, has derivative rights to a cause of action possessed by the subsidiary. Double derivative actions can redress wrongs directly inflicted upon the parent corporation as well as those inflicted on the subsidiary. See 13 FLETCHER, supra note 2, \$ 5977 (1990 Supp.).

149 See Sternberg, 550 A.2d at 1108 . Specifically, the complaint alleged that RKO had failed to disclose an SEC investigation of GenCorp in license renewal proceedings before the FCC. As a result, the FCC allegedly denied the license renewal application of a Boston television station owned by RKO. See id.

${ }^{150}$ See Sternberg v. O'Neil, 532 A.2d 993, 998-99 (Del. Ch. 1987), rev'd, 550 A.2d 1105 (Del. 1988).

151 See id. at 995.

$152 \mathrm{See}$ id. at 997 . The court acknowledged that courts were split as to whether statutory consent can constitute a proper basis for jurisdiction in the absence of minimum contacts. The court was ultimately swayed by language in Burger King which stated that where "forum-selection provisions have been obtained through 'freely negotiated' agreements and are not 'unreasonable and unjust,' . . . their enforcement does not offend due process." Id. (quoting Burger King Corp. v. Rudzewicz, 471 U.S. $462,472 \mathrm{n} .14$ (1985)). The court interpreted this language to mean that any assertion of jurisdiction must be "reasonable and just," and therefore minimum contacts must exist even when a corporation has statutorily consented to jurisdiction by registering to do business in a state. Id. In light of $A s a h i$, the chancery court could have also adopted the position that this was one of the rare instances where even though minimum contacts may have been established by GenCorp's statutory consent to jurisdiction, the exercise of jurisdiction would nevertheless be unreasonable and unconstitutional. See Asahi Metal Indus. Co. v. Superior Court, 480 U.S. 102, 116 (1987) (Brennan, J., concurring in part and concurring in the judgment); supra notes 55-57 and accompanying text.

153 See Stermberg, 532 A.2d at 998. 
to the litigation and, as a result, minimum contacts between GenCorp and Delaware were lacking. ${ }^{154}$

The Delaware Supreme Court reversed the chancery court's decision on two grounds. First, the court ruled that jurisdiction based on voluntary express consent, exhibited by registering to do business in a state and appointing an agent to receive service of process, was a "valid basis for the exercise of general jurisdiction in the absence of any other basis for the exercise of jurisdiction, i.e. 'minimum contacts.' 155 The court's analysis could easily have ended there. GenCorp would then have had to defend itself in the Delaware courts due to its express consent to general jurisdiction in Delaware.

The decision did not end there, however, and the language that followed could have a major impact on future jurisdictional decisions based on the parent-subsidiary relationship. The court went on to hold that in a double derivative action, a foreign corporation's ownership of a Delaware corporate subsidiary constitutes a due process minimum contact sufficient for Delaware courts to exercise jurisdiction over the parent corporation. ${ }^{156}$ One of the most important factors in the Sternberg court's determination that GenCorp had established minimum contacts with Delaware was GenCorp's decision to operate RKO as a Delaware corporation for more than thirty years:

The decision to reincorporate or not to reincorporate in a particular jurisdiction is a deliberate one....

Although scholars may debate its motivation, the fact remains that ... GenCorp has made the conscious decision to operate RKO ... as a Delaware corporation. For more than thirty years, GenCorp has benefitted from the protections of the Delaware law in operating RKO .... We conclude that GenCorp intentionally established and maintained minimum contacts with Delaware by its decision to continue to operate its wholly owned subsidiary, RKO General, as a Delaware corporation. ${ }^{137}$

154 See id.

${ }^{155}$ Sternberg v. O'Neil, 550 A.2d 1105, 1111 (Del. 1988).

156 See id. at 1125 .

157 Id. at 1121-22 (emphasis added). The court also ruled that the fact that RKO was purchased rather than incorporated by GenCorp was a distinction without significance in its minimum contacts analysis. See id. at 1121 . This ruling is justifiable because both the act of incorporating a subsidiary and the act of purchasing a subsidiary can be considered "jurisdictional acts" in the subsidiary's state of incorporation. Under Helicopleros, specificjurisdiction would therefore be present for litigation arising out of either of these acts. The problem with Sternberg is that it is 
Having ruled that minimum contacts existed, the court went on to evaluate those contacts in light of other considerations in order to determine whether the assertion of personal jurisdiction would pass constitutional muster. The other factors which the court examined included a finding that Delaware had "an interest in holding accountable those responsible for the operation of a Delaware corporation, ${ }^{158}$ and that a single proceeding would be an efficient way to resolve the double derivative suit. ${ }^{159}$ The court also noted that the state of incorporation of the subsidiary might be the only forum in which both the parent and subsidiary could be sued in a double derivative action. ${ }^{160}$ These considerations "compelled" the court to conclude that Delaware courts could exercise jurisdiction over GenCorp. ${ }^{161}$

The court did briefly address the issue of whether jurisdiction might be proper based on an analysis of the nature of the parentsubsidiary relationship. Such an analysis would involve an examination of the extent to which GenCorp controlled RKO and/or whether the separation between GenCorp and RKO should be recognized at all. ${ }^{162}$ Although the court recognized the merit of such an approach and implied that jurisdiction over GenCorp could have been based on such findings, the court made clear that its "analysis [made] it unnecessary to base a finding of specific jurisdiction upon ... these theories."163

Curiously, the court did pay lip service to the Cannon doctrine by confirming that " $\mathrm{j}]$ ] urisdiction over a wholly owned Delaware subsidiary does not automatically establish jurisdiction over the parent corporation in any forum. ${ }^{.164}$ Despite its mention, the

difficult to envision how plaintiff's derivative claim "arose" from GenCorp's purchase of RKO 30 years previously.

${ }_{158} I d$. at 1123 .

159 See id. at 1124.

160 See id.

161 See id. at 1125. Whether these considerations "compelled" the court to exercise jurisdiction over GenCorp is arguable. Still, these case-specific considerations do present strong arguments in favor of exercising jurisdiction over GenCorp in this particular case. See infra notes 189-92 and accompanying text. The encompassing language in Sternberg implies, however, that the exercise of jurisdiction over parent corporations would be constitutionally permissible even when the litigation is not in the form of a double derivative suit.

162 See Sternberg, 550 A.2d at 1125-26 n.45 (citing Brilmayer \& Paisley, supra note 60 , in their analysis of when courts may exercise jurisdiction over parent corporations based on the actions of the parents' subsidiaries).

163 Id. at 1126 n.45.

164 Id. at 1119-20 (emphasis omitted) (citing Cannon Mfg. Co. v. Cudahy Packing 
Cannon doctrine apparently played no role in the court's determination that the basic decision to operate a subsidiary as a Delaware corporation constitutes a minimum contact sufficient to satisfy due process in the jurisdictional context. ${ }^{165}$ The Cannon doctrine would be devoid of meaning if the decision to operate a subsidiary in a particular state were a sufficient minimum contact for that state to exercise jurisdiction over the parent corporation.

\section{The Scope of Sternberg}

To this author's knowledge, no other state or federal court decisions that involved suits against a parent and subsidiary in the subsidiary's state of incorporation have based a grant of jurisdiction over nonresident parent corporations on the reasoning used in Sternberg. ${ }^{166}$ Furthermore, even Delaware's lower courts have construed Sternberg narrowly. In Red Sail Easter Ltd. Partners v. Radio City Music Hall Productions, ${ }^{167}$ plaintiff claimed that the Sternberg holding authorized Delaware courts to exercise personal jurisdiction over parent corporations in any causes of action arising out of the operation of Delaware subsidiaries. ${ }^{168}$ The chancery court noted that this principle would be "breath-taking in scope. It would apply for example to support jurisdiction over a New York corporation that owned a Delaware subsidiary whose employee was involved, during the course of his employment, in an intersection collision in Los Angeles." 169 In Red Sail, the court ultimately held that jurisdiction over the nonresident parent was not authorized by

Co., 267 U.S. 333 (1925)).

165 See supra text accompanying note 157.

166 See, e.g., Bielicki v. Empire Stevedoring Co., 741 F. Supp. 758 (D. Minn. 1990) (adhering to the Cannon doctrine in holding that jurisdiction over the parent of a local subsidiary was not unconstitutional); Afros S.P.A. v. Krauss-Maffei Corp., 624 F. Supp. 464 (D. Del. 1985) (holding that due process requires more than the ownership of a Delaware subsidiary in order to exert jurisdiction over a parent corporation in a patent infringement suit), aff', $848 \mathrm{~F} .2 \mathrm{~d} 1244$ (Fed. Cir. 1988) (this holding is arguably no longer valid in light of Stermberg); J.M. Sahlein Music Co. v. Nippon Gakki Co., 243 Cal. Rptr. 4 (Ct. App. 1987) (dismissing claims against the parent in a suit against a parent and subsidiary in the subsidiary's state of incorporation for lack of jurisdiction on due process grounds); Yarborough \& Co. v. Schoolfield Furniture Indus., Inc., 268 S.E.2d 42, 44 \& n.1 (S.C. 1980) (citing Cannon in its holding that the "mere acquisition and control of a domestic subsidiary's capital stock does not subject the foreign parent to the jurisdiction of that State's courts," and dismissing the action on due process grounds).

167 No. 12036, 1991 Del. Ch. LEXIS 113 (July 10, 1991).

$168 I d$. at $\$ 3$.

${ }^{169}$ Id. at $* 4$ n. 2 . 
Delaware's long-arm statute, ${ }^{170}$ and the court therefore never reached the issue of whether jurisdiction would have been constitutional under the Sternberg analysis. ${ }^{171}$ The Red Sail holding is not necessarily inconsistent with Sternberg because Stemberg did not consider whether jurisdiction over GenCorp would have been valid under Delaware's long-arm statute. ${ }^{172}$

Clearly, the implications of the Delaware Supreme Court's decision in Stermberg will depend on how broadly its holding is applied in future cases. If, as Red Sail would seem to indicate, the Delaware long-arm statute would prohibit the exercise of jurisdiction where the facts are similar to those in Sternberg (assuming

${ }^{170}$ In order to lay within the reach of the Delaware long-arm statute's provisions for specific jurisdiction, a claim must arise from a transaction of business in Delaware or a defendant must have caused a tortious injury in Delaware by an act or omission in Delaware. See DEL CoDE ANN. tit. 10, $\$ 3104$ (Supp. 1990). In ruling that the provisions of the long-arm statute had not been met, the court ruled that the claims did not arise from the transaction of business in Delaware (i.e. the incorporation of the subsidiaries) and that the act of forming the subsidiaries in Delaware was "no part of any wrong (in [Delaware] or outside of it)." Red Sail, 1991 Del. Ch. LEXIS 118, at *7-*8.

${ }^{171}$ See Red Sail, 1991 Del. Ch. LEXIS 113, at *5-*6. In the Red Sail litigation, the chancery court did eventually directly confront the issue of whether jurisdiction over the nonresident parent corporation would have been constitutional under the Stermberg analysis. See Red Sail Easter Ltd. Partners v. Radio City Music Hall Prods., No. 12036, 1992 Del. Ch. LEXIS 143 (July 17, 1992). The chancery court construed Sternberg very narrowly and held that Sternberg was a "double derivative suit exception to the general rule that ownership of stock in [sic] corporation does not ususally count as an affiliating contact for "minimum contact' purposes." Id. at *16. The chancery court's July 17, 1992 opinion was, however, withdrawn one week after having been issued, and it is consequently of no precedential value. See Red Sail Easter Ltd. Partners v. Radio City Music Hall Prods., No. 12036, 1992 WL 181030 (Del. Ch. July 23, 1992) (withdrawing the July 17, 1992 Red Sail opinion and ordering that it not be circulated to law libraries or computer data base services).

172 Red Sail may, however, be inconsistent with previous Delaware Supreme Court decisions which state that the Delaware long-arm statute confers jurisdiction to the maximum extent allowed by the Constitution. See infra notes 173-74 and accompanying text.

The only other recent decision interpreting the scope of Stermberg is Applied Biosystems, Inc. v. Cruachem, Ltd., 772 F. Supp. 1458 (D. Del. 1991). In Cruachem, the court analyzed the constitutionality of exercising jurisdiction over a nonresident parent of a subsidiary for injuries occurring outside of Delaware. In the court's constitutional analysis, the only mention of Stemberg was that it authorized "the exercise of specific jurisdiction in a suit involving the duties and responsibilities of Delaware corporations." Id. at 1471 (emphasis omitted). The court went on to say that Sternberg did "not support the proposition that ownership of a Delaware subsidiary qualifies as a continuous and systematic contact with Delaware under a general jurisdiction theory." Id. Thus, Cruachem does little to define the scope of Stemberg other than to point out that the Sternberg court did net purport to be exercising general jurisdiction over GenCorp by virtue of its ownership of RKO. 
GenCorp had not consented to general jurisdiction), then the court's holding in Sternberg will have little significance (except to reinforce the constitutionality of exercising jurisdiction over parties that have consented to such jurisdiction under applicable Delaware statutes). The Red Sail holding may, however, be overturned in light of a previous holding by the Delaware Supreme Court that the Delaware long-arm statute should be "construed to confer jurisdiction to the maximum extent possible under the due process clause." ${ }^{\text {173 }}$ Furthermore, even if the Delaware state long-arm statute would not permit jurisdiction under the facts in Sternberg, it could always be amended to permit jurisdiction to the maximum extent possible under the Constitution. ${ }^{174}$

Assuming, arguendo, that the Delaware long-arm statute did permit the exercise of jurisdiction so long as it were compatible with due process, an argument can be made that the language in Sternberg is so broad that it confers general jurisdiction upon Delaware courts over nonresident parent corporations who choose to avail themselves of the benefits of Delaware law by incorporating or purchasing subsidiaries in Delaware. If this is the appropriate construction of the Delaware Supreme Court's holding, then the decision is almost certainly unconstitutional. Such a construction would permit the exercise of jurisdiction over parent corporations in claims completely unrelated not only to the forum state, but also to the subsidiary incorporated in the forum state. In Shaffer, the United States Supreme Court squarely rejected the notion that the mere ownership of property in the forum state could serve as a constitutional basis for exercising jurisdiction over the property owner. ${ }^{175}$

A narrower and more reasonable reading of Sternberg is that a

173 LaNuova D \& B v. Bowe Co., 513 A.2d 764, 768 (Del. 1986). In Red Sail, Chancellor Allen argued that, in his opinion, "the [Delaware] Supreme Court did not intend in LaNuova to direct the trial court to ignore the specific words of [Delaware's long-arm statute] and to henceforth analyze all questions arising under [the long-arm statute] only in the broad terms of fundamental fairness that guide the determination of the constitutional question." Red Sail, 1991 Del. Ch. LEXIS 113, at *11.

174 Many states do permit jurisdiction to the maximum extent possible under the Constitution. See, e.g., CAL. CIV. PROC. CODE \$ 410.10 (West 1973) (delegating to each court in California "the power to exercise jurisdiction on any basis or contact not denied it by the . . . federal Constitution"). If states such as California were to employ a Stemberg-type analysis in exercising jurisdiction over nonresident parent corporations, the parent corporations could persuasively argue that their constitutional rights had been violated.

175 See Shaffer v. Heitner, 433 U.S. 186, 209 (1977). 
court's jurisdiction over a nonresident parent is constitutionally permissible whenever the subsidiary plays a role in bringing about the cause of action. Such an exercise of jurisdiction would be more analogous to "specific" rather than "general" jurisdiction since the parent would not be amenable to suit in the subsidiary's state of incorporation in claims completely unrelated to the subsidiary.

It could be argued that Sternberg should be construed even more narrowly and that jurisdiction over a nonresident parent should be limited to instances where the subsidiary was acting pursuant to the laws of its state of incorporation. This argument is based on the premise that the parent only availed itself of the benefits of the laws of the state of incorporation in its decision to operate the subsidiary there, and therefore only actions taken pursuant to those laws should subject a parent to jurisdiction. ${ }^{176}$ The parent could not, however, be brought into the courts of its subsidiary's state of incorporation if the litigation was related to acts committed by the subsidiary in other states pursuant to the laws of those states. ${ }^{177}$ It is quite possible that the Sternberg court had this latter construction in mind when it held that jurisdiction was proper "to hear and decide Sternberg's double derivative complaint ${ }^{\text {n178 }}$ and did not discuss the constitutionality of such jurisdiction in other types of actions. ${ }^{179}$ This very narrow reading of Sternberg constitutes a very tenuous limitation on the court's holding. Much of the language in Sternberg is very broad, and does not appear to be limited to situations involving double derivative suits. Furthermore, the very existence of a subsidiary is made possible by the laws of its state of incorporation. Therefore, any actions the subsidiary takes are made possible by the laws of the subsidiary's state of incorporation and any benefits that the parent corporation derives from the actions of its subsidiary are made possible by the laws of that state as well.

${ }^{176}$ For example, a Delaware subsidiary may effectuate a merger or sign a contract pursuant to the laws of Delaware. A parent would be subject to jurisdiction in Delaware in any litigation arising from such acts.

${ }^{177}$ The parent would not be subject to jurisdiction in its subsidiary's state of incorporation, for example, in a products liability suit arising from the subsidiary's manufacture and sale of a product in another state.

178 Sternberg v. O’Neil, 550 A.2d 1105, 1125 (Del. 1988).

179 A double derivative suit clearly falls into the category of cases that involve the laws of the subsidiary's state of incorporation in that those laws define the duties of officers and directors of the subsidiary. 


\section{The Constitutionality of Stermberg}

Constitutionally, it makes little difference which of the two above "narrower" readings of Sternberg is the most appropriate one. Stermberg's holding is constitutionally suspect regardless of whether it applies to any actions of the subsidiary or only to actions taken by the subsidiary which are controlled by the law of its state of incorporation, especially since the Cannon doctrine arguably still constitutes good law. ${ }^{180}$ The court in Sternberg chose not to consider the nature of the relationship between GenCorp and RKO (in terms of assessing the extent to which GenCorp controlled RKO); ${ }^{181}$ instead, its decision was based on the mere existence of the parent-subsidiary relationship and the existence of that relationship for a period of over thirty years. ${ }^{182}$ Such a basis for exerting jurisdiction over a non-resident parent corporation was squarely rejected in Cannon. ${ }^{183}$

The Stermberg decision may not pass constitutional scrutiny even under the assumption that the Cannon doctrine has been completely superseded by International Shoe and its progeny, although its validity rests on stronger footing under such an assumption. The first hurdle that the Stemberg decision would have to pass is the United States Supreme Court's decision in Shaffer. The exercise of specific jurisdiction over GenCorp resembled the very type of jurisdiction that the Shaffer Court appeared to reject: jurisdiction based solely on the ownership of property (i.e., RKO's stock) within the forum state. ${ }^{184}$

${ }^{180}$ See supra notes 58-84 and accompanying text. Even in jurisdictions that have rejected the Cannon doctrine, the holding in Stermberg would be suspect because courts in many such jurisdictions tend to examine the nature of the parent-subsidiary relationship (i.e., the extent to which the parent controls the subsidiary), rather than the mere existence of such a relationship, in reaching jurisdictional conclusions. See supra notes 70-74 and accompanying text.

181 See Sternberg, $550 \mathrm{~A} .2 \mathrm{~d}$ at 1121.

182 See id. at 1122.

${ }^{183}$ Jurisdiction based solely on the existence of a parent-subsidiary relationship was also apparently rejected in Keeton. See supra notes $62-63$ and accompanying text.

184 See supra notes 26 \& 93-97 and accompanying text. As mentioned previously, the Shaffer court implied that had the Delaware Legislature enacted some sort of consent statute whereby persons becoming officers and directors of Delaware corporations would be deemed to have consented to jurisdiction over themselves in Delaware, such a statute would have been upheld. See Shaffer v. Heitner, 433 U.S. 186, 216 (1977). An argument can be made that if Delaware adopted a statute whereby parent corporations that decide to incorporate or purchase Delaware subsidiaries are deemed to have consented to general jurisdiction in Delaware, then jurisdiction over any parent of a Delaware subsidiary would be valid. Clearly, the 
Under World-Wide Volkswagen it is questionable whether a nonresident parent corporation can "reasonably anticipate" being haled into court in its subsidiary's state of incorporation when the only contact the parent has with the forum is the ownership of the subsidiary for a significant period of time. ${ }^{185}$ Since the purpose of creating a subsidiary is to limit the substantive liability of the parent for actions of the subsidiary, a parent might reasonably expect that it will not be forced to defend itself in the subsidiary's state of incorporation absent some sort of piercing of the corporate veil. The Sternberg court relied on the notion that a parent "purposefully avails" itself of the laws of the forum state when it decides to operate a subsidiary in that state ${ }^{186}$ (and, therefore, presumably the parent should reasonably anticipate being haled into the courts of that state). This argument is suspect because it renders ownership of virtually any property within a forum to be purposeful availment of the forum's laws. Under this line of reasoning, the purchase of barren land would arguably constitute purposeful availment of a state's property tax laws, yet the purchaser can hardly be said to have availed herself of the state's laws sufficiently to expect to have to defend herself in suits unrelated to the ownership of the land itself. ${ }^{187}$

Finally, the Supreme Court's decision in Asahi also raises doubts as to Sternberg's constitutional validity even if the Delaware Supreme Court was correct in determining that a parent establishes minimum contacts with Delaware by choosing to operate a subsidiary there. Asahi made clear that in some instances, jurisdiction over a nonresident party may offend traditional notions of fair play and substantial justice even if that party has minimum contacts with the

Delaware Supreme Court would find such a manner of exercising jurisdiction valid in light of its Sternberg holding that express consent to jurisdiction suffices even in the absence of minimum contacts with the forum state. See Sternberg, 550 A.2d at 1111. However, such a statute could be held unconstitutional if the Supreme Court were to unequivocally hold that the Cannon doctrine is still valid law. Furthermore, the Supreme Court has not equivocally sustained or rejected the constitutional validity of jurisdiction based on express consent in the absence of independent minimum contacts. For a thorough discussion of this issue, see id. at 1111-16; Sternberg v. O'Neil, 532 A.2d 993, 995-97 (Del. Ch. 1987), rev'd, 550 A.2d 1105 (Del. 1988).

185 See supra notes 36 \& $98-99$ and accompanying text.

186 See Sternberg, 550 A.2d at 1120 (quoting Papendick v. Bosch, 410 A.2d 148, 152 (Del. 1979), cert. denied, 446 U.S. 909 (1980)).

187 The Sternberg decision may be defensible to the extent that the "purchaser" would only have to defend herself in the forum state against causes of actions related to the property she "purchased." Still, this line of reasoning was apparently rejected in Shaffer. See supra notes $93-97$ and accompanying text. 
forum state. 188 Thus, even if a parent's decision to incorporate a subsidiary in another state is considered a "minimum contact" with the state, it may well be the case that exercising jurisdiction over the parent would be unconstitutional, especially if the parent has no connection to that state other than ownership of its subsidiary's stock.

The strongest arguments supporting the constitutional validity of Stermberg stem from the case-specific facts. The court was surely correct in noting that the most efficient disposition of a double derivative suit would be through litigation in a single forum. ${ }^{189}$ In fact, a double derivative suit can only be litigated in one forum: if either defendant cannot be joined in the suit, the suit must be dismissed for failure to join an indispensable party. ${ }^{190}$ As a result, it is possible that the subsidiary's state of incorporation may be the only forum in which a suit such as the one that the court faced in Sternberg can be litigated at all. ${ }^{191}$ Still, the court considered these factors only after having determined that GenCorp had "intentionally established and maintained minimum contacts with Delaware." 192

Thus, the case-specific facts in Sternberg may justify the court's determination that Delaware courts could constitutionally exercise jurisdiction over GenCorp. However, the court's determination that GenCorp established minimum contacts with Delaware by deciding to purchase and operate a subsidiary there seems to have been based on a faulty constitutional analysis. The court simply ignored the Cannon doctrine, and its analysis is, at best, questionable under International Shoe and its progeny. Thus, the holding in Sternbergthat a parent corporation establishes minimum contacts with a forum when it decides to operate a subsidiary there-will, in all probability, be deemed unconstitutional if a similar constitutional analysis is applied in the context of claims other than double derivative suits where there are alternative forums to sue the parent corporation.

188 See supra notes 45 \& $102-03$ and accompanying text.

189 See Sternberg, 550 A.2d at 1124.

190 See id.

191 See id. In Shaffer, the United States Supreme Court left open the possibility that the presence of defendant's property (in this case, the stock of the subsidiary) in the forum might be a sufficient basis for jurisdiction even in the absence of minimum contacts when no alternative forums are available to the plaintiff. See Shaffer v. Heitner, 433 U.S. 186, 211 n.37 (1977).

192 Sternberg, 550 A.2d at 1122. 


\section{CONCLUSION}

The above analysis reveals that a nonresident corporation's decision to incorporate, purchase and/or operate a subsidiary as a Delaware corporation will most likely be within the constitutional reach of the Delaware courts. Such a result is clearly justified and constitutional if the subsidiary is a mere instrumentality, alter-ego, or agent of the parent corporation, or if the parent corporation's very jurisdictional act (of incorporating a subsidiary, for example) gives rise to the claims against it. A persuasive argument can be made, however, that the exercise of jurisdiction over a parent corporation would be inconsistent with Cannon and would not comport with due process if the parent's specific jurisdictional act did not give rise to or was not related to the cause of action. A broad reading of the Delaware Supreme Court's decisions in Papendick and Sternberg indicates that the court has apparently rejected this argument. Because those decisions have been construed narrowly by Delaware's lower courts, however, the extent to which nonresident parent corporations will be forced to defend themselves in the Delaware courts is unclear.

Part of the confusion surrounding the question of when the exercise of jurisdiction over a parent corporation based on its ownership of a subsidiary is constitutionally valid is due to the lack of specific United States Supreme Court guidance in this area. In particular, lower courts have struggled in determining how to apply the Cannon doctrine, if at all. Still, the Supreme Court's minimum contacts test first adopted in International Shoe does offer some guidelines which lower state and federal courts are bound to follow and most courts seem to adhere to the principles set out in Cannon as well. Many aspects of the Delaware Supreme Court's constitutional analysis in its Sternberg and Papendick decisions are at odds with the United States Supreme Court's jurisdictional due process guidelines. As a result, the analysis in Sternberg and Papendick may not withstand the scrutiny of the United States Supreme Court, if it is extended to claims involving slightly different factual scenarios. In light of the policy arguments favoring the treatment of a parent and subsidiary as separate corporate entities for jurisdictional purposes when they are, in fact, operated as separate corporations, a rejection of the Stemberg and Papendick analysis is warranted. 